\title{
Multivocal Prejudices and Homo Equality
}

\author{
Addison C. Harris Lecture \\ October 27, 1998
}

WILLIAMN.ESKRIGE, JR."

In the last generation, more than half the states have repealed their laws criminalizing consensual sodomy, and many cities and some states have adopted laws prohibiting private as well as public discrimination on the basis of sexual orientation. ${ }^{1}$ Nonetheless, there are today more antigay statutes, rules, and regulations than ever before. The laws take three different forms. Some, such as the exclusion of gay people from the armed forces, no-promotion-of-homosexuality ("no promo homo") policies, and presumptions against custody or adoption by gay people, explicitly discriminate on the basis of sexual orientation. ${ }^{2}$ Other laws, such as bans against same-sex marriage and sodomy laws applying only to same-sex behavior, discriminate on the basis of sex, not sexual orientation; ${ }^{3}$ but their overwhelming effect is against gay people, and homophobia is what keeps these laws on the books. Finally, some laws without sex or sexual orientation classifications have discriminatory effects on gay people: general sodomy laws which criminalize consensual intimacy and laws prohibiting race, sex, and other forms of discrimination, but not sexual orientation discrimination. ${ }^{4}$ Such statutes deprive gay people of privacy and nondiscrimination protections taken for granted by other Americans.

* John A Garver Professor of Jurisprudence, Yale Law School. This Article is the published version of my October 1998 Addison Harris Lecture at Indiana University School of LawBloomington. I am grateful for the questions and comments I received after the lecture and at presentations of this Article at the law schools of Georgetown University, the University of Minnesota, and George Mason University. I most appreciate questions raised by Margaret Brinig, Mary Louise Fellows, David McGowan, and Suzanna Sherry.

1. See WIIIIAMN. ESKRIDG, JR, GAYLAW: ChALLENGING THE APARTHED OF THE ClOSET apps. 2A, 2E (forthcoming 1999).

2. For cases discriminating against gay parents in custody disputes, see, for example, $S . v . S$, 608 S.W.2d 64 (Ky. Ct. App. 1980); GA. v. D.A., 745 S.W.2d 726 (Mo. Ct. App. 1987); and Roe v. Roe, 324 SE.2d 691 (Va. 1985). For bans against adoption by gay people, see FLA. STAT. ANN. $\$ 63.042(3)$ (West 1997), and In re Appeal of Pima County Juvenile Action B-10489, 727 P.2d 830 (Ariz. Ct. App. 1986). The armed forces exclusion is 10 U.S.C. $\$ 654$ (1994). These antigay exclusions are analyzed in WIILIAMN. ESKRIDGE, JR. \& NAND. HUNTER, SEXUALITY, GENDER, AND THE LAW 388-407 (1997).

3. See, e.g., Defense of Marriage Act, 28 U.S.C. § 17376 (Supp. II 1996).

4. For cases excluding sexual orientation discrimination from Title VII, see, for example, Dillon v. Frank, No. 90-2290, 1992 WL 5436 (6th Cir. Jan. 15, 1992) (gay man harassed by coworkers); Ullane v. Eastern Airlines, 742 F.2d 1081 (7th Cir. 1984) (transsexual); De Santis v. Pacific Telephone \& Telephone Co., 608 F.2d 327 (9th Cir. 1979) (discrimination and/or harassment claims by effeminate man, lesbian couple, and other gay people); and Katharine M. Franke, What's Wrong with Sexual Harassment?, 49 STAN. L. REV. 691 (1997) (exhaustive survey of cases). See also 29 U.S.C.A. $\$ 705$ (20)(F)(i) (West 1999) (excluding transvestites and transsexuals from previous protection under Rehabilitation Act); 42 U.S.C. \& 12208 (1994) (excluding transsexualism, transvestism, and homosexuality from "disabilities" covered under the Americans with Disabilities Act). 
All of these laws might be said to violate the core principle of the Equal Protection Clause, that similarly situated people must be treated similarly by the state. Although gay people have long accepted this kind of claim, their attorneys have rarely pressed it in court, and equal protection attacks on antigay policies have almost never been successful. The Supreme Court's decision in Bowers v. Hardwick, ${ }^{5}$ upholding the constitutionality of laws criminalizing consensual "homosexual sodomy," as the Court put it, created a popular syllogism for denying homo equality: because the state can make "homosexual conduct" a felony, surely it can also stigmatize "homosexuals" as presumptive felons. The greater power (criminalization) surely includes the lesser (civil disabilities). This syllogism has shown cracks in the 1990s, however. For the first time in American history, federal as well as some state courts have applied equal protection guarantees for the benefit of gay people. Thus, the Supireme Court ruled in Romer v. Evans ${ }^{6}$ that a state initiative revoking local sexual orientation discrimination ordinances violated the Equal Protection Clause if disconnected from public-regarding policies and adopted, instead, because of antigay animus. Evans could be read, broadly, to support other challenges to federal and state policies discriminating against gay people because of their minority orientation. As for sex-based classifications harming them, gay people can argue that the Supreme Court's precedents support the Hawaii Supreme Court's determination in Baehr v. Lewin' that exclusion of same-sex couples from civil marriage is constitutionally problematic sex discrimination.

These are all logical readings of the Equal Protection Clause and the Supreme Court's precedents. But they are hardly inevitable. Evans contains broad language supporting claims for homo equality, but it arose in a unique factual setting that could render it sui generis. Baehr is more clearly reasoned but represents only the construction of a state constitution and may not be followed by other courts, including the United States Supreme Court. The first Part of this Article will explore the doctrinal implications of Evans for other antigay policies and will suggest those that would appear most vulnerable under that precedent, including the Hardwick suggestion that "homosexual" sodomy might be criminalized even if "heterosexual" sodomy is not. The second Part of the Article will address the sex discrimination argument for homo equality, particularly in the context of same-sex marriage. For both kinds of arguments, there is a fair amount of doctrinal play. Moreover, many scholars and judges believe that courts dare not press the implications of homo equality, out of fear of an antigay backlash that could undermine courts' legitimacy. The last Part of this Article suggests a normative political theory that supports a principled and progressive role for the judiciary even under pragmatic assumptions.

Larger doctrinal, political, and cultural themes will flow from the analysis I have outlined. Antigay state policies are the current testing ground for equal protection jurisprudence. The United States Supreme Court faces a dilemma. The analytical

5. 478 U.S. $186(1986)$.

6. 517 U.S. 620 (1996).

7.852 P.2d 44 (Haw. 1993), on remand sub nom. Baehr v. Miike, CIV. No. 91-1394, 1996 WL 694235 (Haw. Cir. Ct. Dec. 3, 1996) (on appeal as of May 1, 1999). 
structure established in the race and sex discrimination cases would be compromised if the Supreme Court turns its back on claims for homo equality, but many judges and most Americans do not consider sexual orientation discrimination analogous to sex or race discrimination and would be horrified if the Court accepted the claims of homo equality. Ironically, identity politics is intense on both sides of this divide: Gay people consider antigay attitudes prejudice that fundamentally compromises their equal participation in society and politics, but the people who hold those attitudes consider them constitutive of their own identities as well as important public values. Judges are not without resources to manage this dilemma, and the last Part of this Article urges a middle course between pragmatist pandering to existing attitudes and kamikaze judicial activism. The middle way consists of cautious judicial insistence that the rule of law fully applies to gay people, that antigay policies be procedurally deliberate and narrowly tailored, and that pockets of toleration be protected.

\section{ANTIGAY POLICIES AND THE EVOLUTION OF EQUAL PROTECTIONLAW}

The Constitution's guarantee of equal protection of the laws is too broad to be applied literally, as all laws discriminate and government could not operate if all its discriminations were continually in question. Any realistic theory of equal protection must find a principle that identifies those situations where serious scrutiny is justified. The framers of the clause and the early Supreme Court decisions focused equal protection attention on laws that subjected a class of citizens to special disabilities unjustified by natural differences. ${ }^{8}$ The original expectations and early cases reflected a class-based approach. Especially when the Justices believed the class burdened by a state rule was a racial minority, mainly African American, they subjected it to serious scrutiny. But the Court cautioned in Plessy v. Ferguson, ${ }^{9}$ the decision adopting the separate-but-equal formula in race cases, that the state was not responsible for private attitudes or actions that were class-based. The Plessy policy proved unstable in the face of evidence that separate-but-equal was simply a way that African Americans were subordinated as a class. By World War II, the Plessy policy was a positive embarrassment, as the New Deal Justices saw apartheid as a matter of racism, alarmingly akin to Nazi racism, for which the state bore direct responsibility. ${ }^{10}$

It was in this context that the New Deal Court, in United States v. Carolene Products Co., "refined equal protection doctrine to justify serious scrutiny when

8. See WILLIAM E. Nelson, ThE FouRTEENTH AMENDMENT (1988); Melissa L. Saunders, Equal Protection, Class Legislation, and Color-Blindness, 96 MicH. L. REV. 245 (1997); Joseph Tussman \& Jacobus tenBroek, The Equal Protection of the Laws, 37 CAL. L. REV. 341 (1949).

9. 163 U.S. 537 (1896).

10. See David M. Bixby, The Roosevelt Court, Democratic Ideology, and Minority Rights: Another Look at United States v. Classic, 90 YALE L.J. 741, 753-65 (1981).

11. 304 U.S. 144, 152 n.4 (1938); see Louis Lusky, Minority Rights and the Public Interest, 52 YALELJ. 1, 20-21 (1942) (articulating a "representation-reinforcing" theory of judicial review based on footnote 4); see also JOHN HART ELY, DEMOCRACY AND DISTRUST 75-77 (1980) (discussing Carolene Products footnote 4). 
class-based legislation was apparently the consequence of prejudice against a discrete and insular minority, such as African Americans and Jews. This theory was a legal process version of traditional equal protection thinking. Judicial activism was justified only in those circumstances where the political process had in an important sense failed, and the Court considered a process infected with prejudice a corrupt process, consistent with American thinking that strongly distanced our democracy from Nazi totalitarianism. This legal process refinement was important background for the Warren Court's landmark decision in Brown $\boldsymbol{v}$. Board of Education, ${ }^{12}$ which invalidated school segregation policies because of their class-based consequences. Brown substantially overruled Plessy because the Justices insisted that the state take some responsibility for private prejudice and affirmative steps to reconstruct itself in a nondiscriminatory way.

Brown was the apotheosis of class-based equal protection theory, adapted for the modern regulatory state. Yet its great success and its great failure planted the seeds of a new focus for the next generation of equal protection cases. Brown's great success was that it swept away hundreds of laws where the state expressly sponsored apartheid, culminating in Loving v. Virginia, ${ }^{13}$ which rendered unconstitutional laws criminalizing different-race marriages, and ultimately committed the judiciary to supervise transitions from segregated to unitary educational and other public systems. Yet this success carried with it the seeds of failure, or at least retreat. The post-Loving cases posed harder issues for the Court, because they typically involved policies that hurt African Americans or other racial and ethnic minorities but did not clearly target them for legal exclusion, and because they were decided in a political context reluctant to expend state resources to redress historic racial inequities. The Court grappled with the distinction between de jure discrimination, which was illegal under Loving, and de facto discrimination, which the Court between 1973 and 1976 ruled was not illegal unless actually motivated by animus against racial minorities. ${ }^{14}$ The de jure/de facto distinction resurrected the Court's pre-New Deal disinclination to hold the state responsible for private prejudice and shifted the focus of equal protection law from a class-based inquiry to a classification-driven one.

Loving itself reflected this important doctrinal shift. Chief Justice Warren's analysis of the miscegenation law ignored its effect on discrete and insular minorities (blacks, most of whom did not want to marry whites) and focused instead on the irrational classification (race) and the illegitimate purpose (racial purity, or white supremacy). Analytically, Loving replaced Brown as the key race case after 1967 , as the Court ruled that policies not invoking race as a classification were not unconstitutional unless plaintiffs could show a racist purpose ${ }^{15}$ and, most provocatively, that policies invoking race as a classification but benefitting discrete

12. 347 U.S. 483 (1954).

13. 388 U.S. 1 (1967).

14. See Washington v. Davis, 426 U.S. 229, 23940 (1976); Keyes v. School Dist. No. 1, 413 U.S. $189,208(1973)$.

15. See Davis, 426 U.S. at 239; Keyes, 413 U.S. at 208. 
and insular minorities are nonetheless constitutionally suspect. ${ }^{16}$ The recent affirmative action cases have turned Brown and the New Deal vision on their heads. Loving also made clear that the Court had essentially adopted an equal protection "double standard": most discriminating laws just have to reveal a "rational basis," a test hard to fail; only those laws using disapproved classifications, such as race and ethnicity, are subjected to "strict scrutiny," and usually invalidated."

Other social movements of the 1960s followed Brown in litigating to overturn policies hurting traditionally subordinated classes, and Loving in asserting that certain classifications are inherently suspect and certain state policies illegitimate. The most significant cases were the sex-and-gender cases. ${ }^{18}$ In Craig v. Boren, the Supreme Court concluded that sex-based classifications are quasi-suspect, mainly because they tend to reflect "archaic and overbroad"19 stereotypes about women and men. ${ }^{20}$ Perhaps because the plaintiffs in Craig were men challenging a rule favoring eighteen- to twenty-one-year-old women, class-based reasoning was largely absent, and the heightened scrutiny rested mainly on classification-based reasoning. In Craig, the Carolene formulation of class was irrelevant anyway, because women are neither insular nor a minority in the population. Finally, the Court emphasized the relationship between suspect classification and illegitimate state goal: Just as the Court would not tolerate race-based classifications that were motivated by a policy of white supremacy or race stereotypes (Loving), so the Court would not tolerate sex-based classifications that were motivated by a policy of gender stereotypes or male supremacy (Craig). ${ }^{21}$ The sex discrimination cases were argued under the Court's double standard but immediately loosened it up. Some sex discriminations were invalidated under the rational basis test, ${ }^{22}$ while others were

16. The Court has been skeptical of such policies since Regents of the University of California v. Bakke, 438 U.S. 265, 290 (1978), and has deepened that skepticism in City of Richmond v. J.A. Croson Co., 488 U.S. 469 (1989), and Adarand Constructors, Inc. v. Pena, 515 U.S. 200 (1995).

17. See Gerald Gunther, The Supreme Court, 1971 Term-Foreword: In Search of Evolving Doctrine on a Changüng Court A Model for a Newer Equal Protection, 86 HARV. L. REV. 1, 37 (1972).

18. These are comprehensively excerpted and analyzed in BARBARA ALLEN BABCOCK ET AL., SEXDISCRMINATION AND THE LAW: HISTORY, PRACTICE, AND THEORY ch. 1 (1996).

19. 429 U.S. 190, 198 (1976).

20. This theme had been sounded in earlier cases. See Frontiero v. Richardson, 411 U.S. 677 (1973) (plurality opinion) (holding a male spouse of an Air Force officer a dependent by the same standards as a female spouse); Stanton v. Stanton, 421 U.S. 7 (1975) (holding a divorcee mother liable for child support); Weinberger v. Weisenfeld, 420 U.S. 636 (1975) (holding differences in social security survivor's benefits based on gender unconstitutional). The theme provided a basis for upholding discriminations in, for example, Schlesinger v. Ballard, 419 U.S. 498 (1975) (upholding differences between male and female Naval officers' mandatory retirement provisions).

21. But compare Schlesinger, 419 U.S. at 507, and Kahn v. Shevin, 416 U.S. 351, 355 (1974), both of which upheld sex discriminations, in part because they were adopted for the permissible purpose of remedying disadvantages suffered by women.

22. See Reed v. Reed, 404 U.S. 71, 76 (1971). 
struck down under heightened-but-not-strict scrutiny, ${ }^{23}$ and yet others were upheld under standards the Court left unclear. ${ }^{24}$

The sexual orientation discrimination cases have followed the pattern of the sex discrimination cases: The legal defense arms of a liberation movement have insisted upon legal equality through equal protection litigation to overturn discriminations against its members; to that effect, gay-friendly lawyers have argued that sexual orientation is a suspect classification, like race, or a quasi-suspect one, like sex, and that morality-based defenses of antigay laws amount to the same kind of inadmissible prejudice as racism and sexism. ${ }^{25}$ It remains to be seen how the Supreme Court will assimilate these arguments into the Court's evolving equal protection jurisprudence, but the Court's first serious effort, Romer v. Evans, is analytically fascinating in its synthesis of that jurisprudence. ${ }^{26}$ Justice Kennedy's opinion opened with the Plessy dissent's objection to class legislation, where one group is excluded from ordinary legal protection. Like Brown and unlike Loving, therefore, Evans emphasized the class-based effects of the Colorado initiative. Keeping the Court's options open, Evans said nothing about whether sexual orientation is a suspect classification, like race or sex, but still struck down the law under the rational basis test, as there was no legitimate state goal for the initiative. Like Loving and unlike Brown, therefore, Evans emphasized the initiative's impermissible purpose, to express animus against gay people.

The Court's assertion that animus rather than morality was the state goal, its belief that the initiative was class-based in the old-fashioned sense, and its sidestepping the level of scrutiny issue but giving the rational basis test sharper teeth, are features of the opinion that justify deeper exploration. Evans commits the Court to no particular posture in future sexual orientation cases and might be viewed as the Court's generous offer to judges and commentators to provide the Justices with further information about antigay laws and their consequences for gay

23. See, e.g., Craig, 429 U.S. at 197; Califano v. Goldfarb, 430 U.S. 199, 210-11 (1977) (social security survivor's benefits); Orr v. Orr, 440 U.S. 268, 279 (1979) (alimony payments by wife for husband).

24. See Michael M. v. Superior Court, 450 U.S. 464 (1981) (statutory rape law); Rostker v. Goldberg, 453 U.S. 57 (1981) (Selective Service Act).

25. Almost all of the early gay equality cases were brought under the Due Process Clause. See William N. Eskridge, Jr., Challenging the Apartheid of the Closet: Establishing Conditions for Lesbian and Gay Intimacy, Nomos, and Citizenship, 1961-1981, 25 HoFsTRA L. REV. 817 (1997). However, cases in the last decade have emphasized equal protection arguments. See ESKRIDGE \& HUNTER, supra note 2, at 92-124, 301-04, 374-404, 638-39, 807-13, 913-37.

26. 517 U.S. 620 (1996). Commentary on this decision has already proliferated. Those that have most influenced my thinking are Akhil Reed Amar, Attainder and Amendment 2: Romer's Rightness, 95 Mich. L. REv. 203 (1997); Daniel Farber \& Suzanna Sherry, The Pariah Principle, 13 CONST. COMMENTARY 257 (1996); Toni Massaro, Gay Rights, Thick and Thin, 49 STAN. L. REV. 45 (1996); Jane S. Schacter, Romer v. Evans and Democracy's Domain, 50 VAND. L. REV. 361 (1997); and Louis Michael Seidman, Romer's Radicalism: The Unexpected Revival of Warren Court Activism, 1996 SuP. CT. REv. 67. The best pre-Evans debate is between Kenneth L. Karst, LAW's PROMISE, LAW's EXPRESSION: VISIONS OF POWER IN THE POLITICS OF RACE, GENDER, AND RELIGION 182-86 (1993), and Richard F. Duncan \& Gary L. Young, Homosexual Rights and Citizen Initiatives: Is Constitutionalism Unconstitutional?, 9 NOTRE DAME J.L. ETHICS \& PUB. POL'Y 93-135 (1995). 
lives, nongay lives, and the idea of equal protection of the laws. In response, academics can offer the Court useful, and complexifying, information about current thinking regarding prejudice, history, and politics, as they relate to gaylegal equality. The remainder of this Article does precisely that, exploring the logical, cultural, and political ramifications of Evans for equal protection challenges to antigay policies.

\section{A. Hardwick and Discriminatory Sodomy Laws}

Evans leaves Hardwick in equal protection purgatory. The earlier decision is distinguishable on its facts, as the Georgia sodomy law had a long Anglo-American pedigree and created a class defined by conduct rather status. The opinion for the Court in Hardwick, however, emphasized that it was only evaluating the constitutionality of laws against "homosexual sodomy,"27 suggesting that "heterosexual sodomy" might be given constitutional protection. This distinction is problematic under Evans. In the long history of sodomy laws, Hardwick's distinction is something of a novelty: It did not show up in state law until 1969:28 it targets gay people for gratuitous, special stigma; and it imposes on gay people a particularly severe disability, potential criminal liability for consensual conduct. Nor are the possible state goals for the Hardwick distinction passable under Evans scrutiny. The most apparent reasons for making oral sex between two women, but not between a woman and a man, criminal would be insistence upon rigid gender roles or social prejudice against gay people. ${ }^{29}$ The first reason is inadmissible under Craig, and the second reason would appear to be problematic under Evans. A third reason, that same-sex sodomy is more likely to spread venereal disease than different-sex sodomy, is rarely advanced by states themselves, because it is unsupported by empirical evidence and has been pervasively rejected by medical health professionals, who maintain that sodomy laws impede the medical campaign against $\mathrm{AIDS}{ }^{30}$

27. Bowers v. Hardwick, 478 U.S. 186,188 \& n.2 (1986).

28. The first state to make only same-sex, and not different-sex, consensual sodomy a crime was Kansas. See 1969 KAN. Sess. LAws § 21-3505. For a history of sodomy laws, which traditionally did not apply to woman-woman intercourse but did apply to man-woman and manman intercourse, see William N. Eskridge, Jr., Hardwick and Historiography, 1999 U. ILL. L. REV. (forthcoming).

29. Revulsion against oral or anal sex per se would not support the Hardwick distinction. If it is okay for Bill and Monica to enjoy oral sex but not for Monica and Linda, the reason cannot be revulsion at oral sex per se. Instead, it must be either a reaction to Monica's violating her gender role in the latter case, or the suggestion that the act reflects an illegitimate desire of Monica for a woman rather than a man.

30. The venereal disease argument is made in, for example, LAWRENCE BURTOFT, SETTING THE

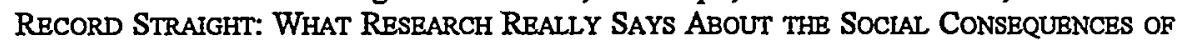
HOMOSEXUALITY 32-35 (1995), and in amicus briefs filed by antigay traditionalists in some sodomy cases, including Hardwick. Public health professionals in sodomy-challenge cases have disavowed such arguments, for reasons discussed approvingly in Gryczan v. State, 942 P.2d 112, 123-24 (Mont. 1997); Campbell v. Sundquist, 926 S.W.2d 250, 263-64 (Tenn. Ct. App. 1996); and Tomas J. Phil IPSON \& Richard A. Posner, PrTvate Choices and Public Health: The AIDS EPIDEMIC IN AN ECONOMIC PERSPECTIVE (1993). 
Evans, therefore, potentially supports an equal protection challenge to state laws criminalizing only same-sex sodomy and should be read as a retreat from, or retraction of, Hardwick's focus on homosexual sodomy alone. But once Hardwick's focus on homosexual sodomy is jettisoned, then the Court's purported rational basis-antihomosexual sentiment-also falls away, ${ }^{31}$ and the Georgia statute might be stranded in the same way the Colorado initiative was, without a legitimate state goal supporting it. This might be so, but the Court has yet to rule on the matter, and Evans deliberately refrained from discussing its implications for Hardwick. ${ }^{32}$ The Court's silence creates a genuine legal puzzle: In a world of both Hardwick and Evans, antigay measures will, potentially, be either defensible as expressions of public antihomosexual morality or vulnerable as expressions of antihomosexual animus. ${ }^{33}$ Hence, a court has discretion as to decision of constitutional questions, depending upon how the judges choose to categorize the claims and defenses in a particular case. ${ }^{34}$

Justice Kennedy's use of the term "animus" in Evans borrows from the race cases and suggests a linkage made by philosopher Elisabeth Young-Bruehl, that homophobia in our society often resembles racial prejudice in its hysterical qualities: Like the archetypical racist, many homophobes view objects of their hatred as dirty people whose fantasized disgusting conduct justifies the homophobe's imagined or acted-out violence against them. ${ }^{35}$ (This feature of homophobia was recently acted out in the torture and murder of Matthew Shephard in Wyoming.) Young-Bruehl adds that homophobia has also traditionally resembled antisemitism in its obsessional qualities. Like Jews, homosexuals are viewed as an advantaged conspiratorial group preying on the homophobe and his kin. ${ }^{36}$ Significantly, she adds, homophobia also resembles sexism in its narcissistic qualities. Like people of the opposite sex, homosexuals are viewed as "The Other,"

31. The Supreme Court ruled that Georgia's criminalization of homosexual sodomy was rationally related to its popular disapproval of homosexuality. See Hardwick, 478 U.S. at 196. But if the Georgia law were applied as it is written, to make different-sex as well as same-sex sodomy a felony, it might not be able to rest upon that basis. As the large majority of heterosexuals commit oral sex, the crime for which Hardwick was arrested, the Georgia law might no longer be supported by popular sentiment.

32. The Court's silence about Hardwick is striking in light of the dissent's insistence that Hardwick foreclosed the Court's result. See Romer v. Evans, 517 U.S. 620, $640-43$ (Scalia, J., dissenting).

33. See Andrew Koppelman, Romer v. Evans and Invidious Intent, 6 WM. \& MARY BILL OF Rights J. 89, 89-90, 138-46 (1997). For a response, see Richard Duncan, The Narrow and Shallow Bite of Romer and the Eminent Rationality of Dual-Gender Marriage: A (Partial) Response to Professor Koppelman, 6 WM. \& MARY BLL OF RIGHTs J. 147 (1997).

34. See Janet E. Halley, Reasoning About Sodomy: Act and Identity in and After Bowers v. Hardwick, 79 VA. L. ReV. 1721 (1993).

35. ELISABETH YOUNG-BRUEHL, THE ANATOMY OF PREJUDICES (1996); see also Gregory M. Herek, Psychological Heterosexism and Anti-Gay Violence: The Social Psychology of Bigotry and Bashing, in HATE CRIMES: CONFRONTING VIOLENCE AGAINST LESBIANS AND GAY MEN 149 (Gregory M. Herek \& Kevin T. Berrill eds., 1992).

36. See YOUNG-BRURH, supra note 35, at 32-34. 
a group whose differentness helps the homophobe define his own sexual identity. ${ }^{37}$ Young-Bruehl's view of the multiple roots of homophobia helps us see what Justice Kennedy might have found disturbing in the Colorado case. The campaign yielding the Evans initiative, conducted by Colorado for Family Values, made arguments closely tracking the hysterial and obsessional arguments previously deployed against Jews and African Americans. Gay people were defined as ADS-diseased because of their "voracious," "high-risk" (anal sex), and promiscuous sexual lives, and as a wealthy group seeking "special rights" so they could be free to "attack" the family and the church and to "indoctrinate" and recruit the state's young people. ${ }^{38}$ The overall thrust of their campaign was highly narcissistic, as it emphasized traditional gender roles that were threatened by gay people.

If Young-Bruehl is right that homophobia is a multivocal, all purpose prejudice, the tension between Evans and Hardwick is deepened. The same multivocal features of homophobia render it particularly virulent from the perspective of the gay person (Evans), but variously attractive and functional from the perspective of the antigay person (Hardwick). This illustrates how identity politics figures into both sides of the issue. Openly gay people's collective identity, and their collective problems, derive from the power of widespread antigay feelings. Contrariwise, homophobia serves identity as well as emotional needs of other people, including many closeted gay people. ${ }^{39}$ That some religions emphasize antigay doctrines means that homophobia also implicates some people's religious identity as well. Because intensely felt political identities are arrayed on both sides of gay rights issues, the Court might be loathe to choose between a full gay equality that would antagonize homophobes and no gay rights that would antagonize gay people and their families. One middle ground between these poles would be that staked out by the Hardwick dissents: toleration of gay people's intimate relations by the state, with private individuals free to shun and dislike the conduct and the people so tolerated. This position, of course, would require the overruling of Hardwick, which is a precedent so riven with problems of accuracy, faimess, and fidelity to precedent that its overruling would serve larger rule of law functions in any event. ${ }^{40}$ This middle ground has the advantage of allowing narcissistic homophobes to differentiate

37. See id; ;ee also ADRIENNE RICH, Compulsory Heterosexuality and Lesbian Existence, in BLOOD, BRRAD, AND POETRY: SELECTED PROSE, 1979-1985 (1986) (stating that compulsory heterosexuality is the way men enforce subordinate status on all women, not just lesbians).

38. The documents used by Colorado for Family Values are reprinted in Robert F. Nagel, Playing Defense, 6 WM. \& MARY BLL OF RIGHTS J. 167, 191-99 (1997), and in ESKRDGE \& HUNTER, supra note 2. See also STEPHEN BRANFORD, GAY POLITICs vs. COLORADO AND AMRRICA: THE INSDE STORY OF AMENDMENT 2 (1994).

39. Consistent with the hysterical qualities of homophobia, many of the most antigay people harbor strong feelings of attraction to people of their same sex.

40. For just a few of the cogent critiques of Hardwick, see generally CHARLES FRIED, ORDER AND LAW 81-84 (1991); RICHARD A. POSNER, SEX AND REASON 341-50 (1992); LAURENCE H. TRIBE, AMERICAN CONSTTIUTIONAL LAW 1421-35 (2d ed. 1988); Eskridge, supra note 28; Anne B. Goldstein, History, Homosexuality, and Political Values: Searching for the Hidden Determinants of Bowers v. Hardwick, 97 YALE L.J. 1073 (1988); Sylvia A. Law, Homosexuality and the Social Meaning of Gender, 1988 WIs. L. REV. 187; Frank Michelman, Law's Republic, 97 YaLE L.J. 1493 (1988); and Jed Rubenfeld, The Right of Privacy, 102 HARV. L. REV. 737 (1989). 
themselves from sexual "Others" without unduly intruding on the privacy of the latter, but would not satisfy obsessional homophobes, who desire to have their enemies out in the open. That the fears of obsessional homophobes seem to have no rational grounding, and for that reason have lost much of their appeal in the last generation, might require that they not trump the human rights of gay people, however.

\section{B. Custody and Adoption}

Although not the first time the Court had given rational basis review greater bite, ${ }^{41}$ Evans was remarkable in the strictness of the Court's examination. Colorado's Amendment 2 prohibited or preempted any law or policy "whereby homosexual, lesbian or bisexual orientation, conduct, practices or relationships shall constitute or otherwise be the basis of or entitle any person or class of persons to have or claim any minority status, quota preferences, protected status or claim of discrimination."42 The State defended the sexual orientation discrimination created by the initiative as rationally related to state policies conserving scarce resources for enforcing civil rights laws, protecting the rights of parents, landlords, and employers not to associate with gay people, and sending a message that homosexuality does not have a state stamp of approval. ${ }^{43}$ All of these policies were apparently more rational than the antihomosexual sentiment held to be a rational basis in Hardwick, but the Evans Court ruled the Colorado initiative invalid, in large part because "its sheer breadth is so discontinuous with the reasons offered for it that the amendment seems inexplicable by anything but animus toward the class that it affects." ${ }^{344}$ The Court characterized the initiative as a status-based law aimed at a class of citizens and held that such laws violate the core equal protection command that " a bare ... desire to harm a politically unpopular group cannot constitute a legitimate government interest. "345

The socio-legal process described above has an historical dimension. In its analysis of the unprecedented and broad class-based disability of the Colorado initiative, the Evans Court ruled that, by revoking the antidiscrimination protection some local ordinances afforded gay people, the initiative deprived them of "protections taken for granted by most people either because they already have them or do not need them; these are protections against exclusion from an almost limitless number of transactions and endeavors that constitute ordinary civic life in

41. See Heller v. Doe, 509 U.S. 312 (1993) (upholding a law disadvantaging the mentally disabled but insisting on objective reason); City of Cleburne v. Cleburne Living Ctr., Inc., 473 U.S. 432 (1985) (striking down a zoning ordinance which disadvantaged the mentally disabled because there was no reason for the law but negative attitudes toward, and fear of the mentally retarded). But cf. Williamson v. Lee Optical, 348 U.S. 483 (1955) (accepting assumed health concerns as a basis for rent-seeking regulation); Railway Express Agency v. New York, 336 U.S. 106 (1949) (allowing a state leeway to regulate piecemeal to achieve speculative goal).

42. Romer v. Evans, 517 U.S. 620, 624 (1996) (quoting CoLo. CoNST. art. II, § 30b).

43. See Petitioners' Brief at 13, Romer v. Evans, 517 U.S. 620 (1996) (No. 94-1039).

44. Evans, 517 U.S. at 631.

45. Id. at 634 (quoting United States Dep't of Agric. v. Moreno, 413 U.S. 528, 534 (1973) (emphasis omitted)). 
a free society." ${ }^{36}$ By delivering Evans on (almost) the one-hundredth anniversary of Plessy and opening the opinion with the class legislation language from the Plessy dissent, the Court rhetorically recognized that the state neutrality required by the equal protection clause is historically situated. Justice Harlan's Plessy dissent was neither color-blind nor antiracist. ${ }^{47}$ Harlan's argument was, instead, that it was socially and politically unproductive for the law to instantiate a class-based system where African Americans were formally pushed to the bottom.

In earlier articles, I have set forth the historical outlines of a similar account of a class-based system where gay Americans were formally pushed to the bottom, albeit a bottom defined by the closet rather than the ghetto. ${ }^{48}$ The state "Kulturkampf" against homosexuals in the 1940s and 1950s was animated by the same kind of hysterical, obsessional, and narcissstic private prejudices that have animated antisemitism, racism, and sexism, respectively. State repression contributed multifariously to an apartheid of the closet, less brutal than racial apartheid was, but equally unproductive. Evans can be read as the Court's recognition that the state contribution to the apartheid of the closet carries with it today a modest state responsibility not to reinforce the closet, as the Colorado initiative sought to do and for reasons that explicitly resonated with traditional tropes of prejudice. Consequently, any state rule that treats gay people as a class deserving less state protection than straight people requires justification going beyond antigay animus.

Consider this historical reading of Evans as applied to rules against adoption by gay people and presumptions against child custody by lesbian, gay, or bisexual parents. These rules are, on their face, neither as unprecedented nor so broadly sweeping as Colorado's initiative was; hence, Evans might be distinguished. On the other hand, the antigay adoption and custody rules have become increasingly isolated; only three states (Arizona, Florida, and Utah) forbid gay people from adopting, and a larger but shrinking number of states presume, in varying degrees of clarity, against child custody for gay parents. ${ }^{49}$ Moreover, states with such antigay policies often fail to apply the same policies against heterosexual fornicators, adulterers, and sodomites. ${ }^{50}$ A recent Florida decision took a child away from its lesbian mother and placed the child with the father, a convicted murderer just released from prison. The court based its decision on the sexual "conduct,"

46. Id. at 631 .

47. See Gabriel J. Chin, The Plessy Myth: Justice Harlan and the Chinese Cases, 82 IowA L. REv. 151 (1996).

48. See William N. Eskridge, Jr., Privacy Jurisprudence and the Apartheid of the Closet, 1946-1961, 24 FLA. ST. U. L. REV. 703 (1997) [hereinafter Eskridge, Privacy Jurisprudence]; William N. Eskridge, Jr., Law and the Construction of the Closet: American Regulation of SameSex Intimacy, 1880-1946, 82 IowA L. REv. 1007 (1997) [hereinafter Eskridge, American Regulation].

49. See supra text accompanying note 2 .

50. Compare Whaley v. Whaley, 399 N.E.2d 1270 (Ohio Ct. App. 1978) (holding that adultery does not disqualify a parent from custody that is otherwise in the best interest of the child), with Conkel v. Conkel, 509 N.E.2d 983 (Ohio Ct. App. 1987) (holding that the same applies to homosexuality, except that the gay father could not visit the children accompanied by another man). 
with consenting adults, of the mother and de-emphasized the conduct of the father, murder of an unconsenting adult. ${ }^{51}$ Florida's open discrimination against adoption or custody by gay parents, in particular, is more historically connected with class legislation than the Colorado initiative was, because Florida was one of the two epicenters of antigay "Kulturkampf" in the 1950s, and Florida's antigay policies create a class of people denied protections even more basic than those denied by the Colorado initiative. Most important, the fit between antigay custody policy and its rationales is so wobbly as to suggest antigay animus as their goal-a goal which would make Evans squarely applicable.

Traditionally, judges reasoned from the existence of sodomy laws that "sodomites"-which gay people presumptively are in hysterical discourse-are per se so immoral that they should be disfavored when the State is involved in child placement. ${ }^{32}$ This hysterical kind of argument has lost most of its force in jurisdictions without sodomy laws and would lose more if Hardwick were overruled. Additionally, as the.large majority of heterosexuals engage in sodomy, there is scant reason to invoke sodomy laws to discriminate against gay people-unless the state sodomy law discriminates, which is itself inconsistent with the core holding of Evans, for the reasons explored above. Finally, the state policy goal in the areas of adoption and custody for some time has been the "best interests of the child." Any effort by the state to use children to make a symbolic statement of animus against gay people is more vicious than the Evans initiative, unless a parent's sodomy can somehow be tied to the child's best interests by a nonobsessional chain of factual reasoning. If it cannot, the antigay policy is not only way underinclusive (it allows most sodomites (the straight ones) to have custody), but it is way overinclusive as well (it excludes (gay) parents who will be the "best" for many children)-precisely the problem that Evans found unconstitutionally irrational in the Colorado initiative..$^{53}$

The foregoing reasons have pressed even traditionalist states away from per se rules against gay parental custody, but some states still have discriminatory presumptions. The modern justification for these presumptions is that gay people are not good parents, or are not as good at parenting as straight people. ${ }^{54}$ Several features of these presumptions suggest that they are driven by prejudice based on antigay feelings, and not the best interests of the child. That they are lineal descendants of the discredited per se rules suggests that the presumptions are modern pretexts for older prejudice-based arguments against gay parenting. The

51. See Ward v. Ward, No. 95-4184, 1996 WL 491692, at *3 (Fla. Dist. Ct. App. Aug. 30, 1996). The mother died soon thereafter, and the court's order was vacated, presumably so that it would not stand as precedent in Florida.

52. See, e.g., Immerman v. Immerman, 176 Cal. App. 2d 122, 127 (Cal. Ct. App. 1959); Bennett v. Clemens, 196 S.E.2d 842, 843 (Ga. 1973); Commonwealth v. Bradley, 91 A.2d 379, 381-82 (Pa. Super. Ct. 1952); Bottoms v. Bottoms, 457 S.E.2d 102, 108-09 (Va. 1995).

53. Romer v. Evans, 517 U.S. 620, 633 (1996).

54. Compare Lynn D. Wardle, The Potential Impact of Homosexual Parenting on Children, 1997 U. ILL. L. REV. 833 (surveying the heterogeneous case law and proposing an omnibus presumption against gay custody, visitation, and adoption), with Carlos A. Ball \& Janice Farrell Pea, Warring with Wardle: Morality, Social Science, and Gay and Lesbian Parents, 1998 U. ILL. L. REV. 253 (responding point-by-point to Wardle). 
pretextual nature of these presumptions is demonstrated by the substantial gap between their antigay policy and the best interests of the child. This suggests that hysteria about dirty homosexual behavior and obsession with fantasized gay predation still underlies the policies.

Dozens of empirical studies have compared the development of children raised by gay parents or households with those reared by straight parents or households. ${ }^{55}$ No study that I have seen unequivocally endorses broad presumptions against gay custody or adoption, and the large majority of the studies specifically support a gayneutral rule most consistent with Evans. Although most of the studies state at the outset that they offer only provisional conclusions given their small and necessarily nonrandom samples, ${ }^{56}$ a recent meta-analysis correcting for small sample size (but not for nonrandomness) found that the data "indicate no difference between homosexual and heterosexual parents," and support rules that do not take sexual orientation into account when making custody and visitation decisions. ${ }^{57}$ On developmental criteria such as self-esteem, adjustment to new circumstances and emotional disorder, the children raised in same-sex parental households are virtually indistinguishable from children raised in different-sex parental households. The few studies that have compared two-mother households with single-mother households have found that children raised in the former are better adjusted than children raised in the latter, whether the single parent is straight or lesbian. ${ }^{88}$ These studies support the Evans-like finding that antigay childrearing presumptions have the weakest connection with the best interests of the child.

55. Leading studies include Patricia J. Falk, Lesbian Mothers: Psychosocial Assumptions in Family Law, 44 AM.PSYCHOLOGIST 941 (1989); Susan Golombok et al., Children in Lesbian and Single Parent Households: Psychosexual and Psychiatric Appraisal, 24 J. CHIID PsYcHOL. \& PSYCHIATR 551 (1983); Mary E. Hotvedt \& Jane B. Mandel, Children of Lesbian Mothers, in HOMOSEXUALITY: SOCIAL, PSYCHOLOGICAL, AND BIOLOGICAL Issues 275, 282 (William Paul et al. eds., 1982) [hereinafter HOMOSEXUALITY IssuEs]; and David J. Kleber et al., The Impact of Parental Homosexuality in Child Custody Cases: A Review of the Literature, 14 BULI. AM. ACAD. PSYCHIATRY \& L. 81 (1986). Competing reviews of the empirical literature are contained in Wardle, supra note 54, and Ball \& Pea, supra note 54.

56. See, e.g., Susan Golombok \& Fiona Tasker, Do Parents Influence the Sexual Orientation of Their Children? Findings from a Longitudinal Study of Lesbian Families, 32 DEVELOPMENTAL PSYCHOL. 3, 8 (1996) (indicating the impossibility of recruiting a random sample of gay parents because of the closetry of most); Charlotte J. Patterson, Children of Lesbian and Gay Parents, 63 CHIIDDEv. 1025, 1036-39 (1992) (surveying the studies, including those of the author). Compare Philip A. Belcastro et al., A Review of Data Based Studies Addressing the Affects of Homosexual Parenting on Children's Sexual and Social Functioning, 20 J. DrvoRCE \& REMARRIAGE 105 (1993) (harsher survey of the studies), with Mike Allen \& Nancy Burrell, Comparing the Impact of Homosexual and Heterosexual Parents on Children: Meta-Analysis of Existing Research, 32 J.HOMOSEXUALITY 19 (1996) (correcting for some of the methodological limits of previous studies).

57. Allen \& Burrell, supra note 56 , at $28-30$.

58. See Richard Green et al, Lesbian Mothers and Their Children: A Comparison with Solo Parent Heterosexual Mothers and Their Children, 15 ARCHIVES OF SEXUAL BEHAVIOR 167 (1986); Golombok et al., supra note 55, at 562-67; Rhonda R. Rivera, Legal Issues in Gay and Lesbian Parenting, in GAY AND LESBIANPARENTs, 199, 226 n.79 (Frederick W. Bozett ed., 1987) (reporting an unpublished study comparing children in households having two lesbian parents, with those in households having a single female parent, whether straight or lesbian). 
The few legal scholars who defend antigay presumptions do so on grounds that can be directly linked to traditional, and rhetorically abandoned, antihomosexual prejudice of the sort that Evans faulted. Professor Lynn Wardle, the leading proponent of antigay family law presumptions, argues that children will be harmed if they are raised by same-sex parents because (1) such parents engage in dirty extramarital conduct, (2) the children of such households tend to depart from and to be confused about traditional gender roles, and (3) the children will tend to become homosexual themselves and may even be molested by their gay parents. ${ }^{59}$ Professor Carlos Ball and Janice Pea argue in impressive detail that there are no factual bases for Wardle's claims that these children are confused, grow up to be gay, or are molested. ${ }^{60}$ Wardle's last assertion is the boldest, as the social science evidence shows that child molestation is overwhelmingly a male activity, with straight men just as or more (depending on the study) prone to it as gay men, and lesbian as well as straight women the least prone. ${ }^{61}$ Added to his surprisingly weak factual claims is the striking way Wardle's argumentation rhetorically tracks prejudice-based antihomosexual rhetoric in this century, namely, (1) the hysterical focus on dirty sexual activities such as sodomy, (2) the narcissistic insistence on rigid gender identities, and (3) the obsessional focus on the predatory homosexual seeking to recruit new homosexuals. As in Evans itself, the weak connection between antigay rules and their ostensible policy goals and the strong connection between antigay rules and traditional prejudice are mutually and powerfully reinforcing.

Compared to antigay child custody rules, Evans poses fewer problems for "don't ask, don't tell" policies by state institutions such as the armed forces. Take the military exclusion of people for self-identifying as bisexual, lesbian, or gay. One rationale for the policy, namely, that the statement is evidence of sodomy which is illegal under military law, is vulnerable if Hardwick bites the constitutional dust. More important, military law prohibits all kinds of sodomy, which is an activity common among straights as well as gays. A woman who says she is a lesbian is only slightly more likely to have engaged in oral sex than a woman who says she is straight, and substantially less likely to have engaged in anal sex (the traditional understanding of sodomy). ${ }^{62}$ Because the gay woman is disciplined under circumstances where a similarly situated straight woman is not, she is denied equal protection of the laws, unless the state can show a non-animus basis for such policies. But the standard arguments for such policies-the lesbian is a disgusting sodomite, violates gender norms, and threatens vulnerable heterosexuals-closely track the hysterical, narcissistic, and obsessional features of classic American race, sex, and ethno-religious prejudices.

On the other hand, the armed forces' "don't ask, don't tell" policy is distinguishable from the Colorado initiative struck down in Evans, as it is no legal novelty and is less sweeping in the disability it imposes on gay people. More

59. Wardle, supra note 54 , at $852-57,865-66$.

60. Ball \& Pea, supra note 54.

61. See, e.g., Carole Jenny et al., Are Children at Risk for Sexual Abuse by Homosexuals?, 94 PEDIATRICS 41 (1994).

62. See EDWARD O. LaUManN ET AL., The Social ORganzation OF SEXUALITY: SEXUAL PRACTICES IN THE UNTED STATES 98-99 (1994). 
important, the institutional context makes the animus argument cut both ways: the armed forces maintain that antigay prejudice stimulated by the presence of openly gay service personnel would be disabling to the morale and unit cohesion needed for an effective military. If Evans is read to question hysterical, narcissistic, and obsessional feelings against gay people as the basis for invading gay people's privacy or discriminating against them in the public sector, it does not necessarily require the state to disregard such feelings when the state thrusts young people into a totalizing setting where they are required to eat, sleep, and shower together. Thus, the armed forces has a more robust argument for its antigay policies than other state agencies have. Judicial deference to military judgments, especially as relates to matters of morale and combat effectiveness, greatly strengthen the argument.

\section{DOMA and No Promo Homo}

Evans is also a starting rather than concluding point for thinking about state statutes or agency rules prohibiting classroom or other state discussion that either "promotes" homosexuality or depicts it as a "positive alternative life-style."63 Like Colorado's Amendment 2, such policies are an unusual and recent innovation, targeting gay people as a class and having a potentially vicious effect on gay adolescents in particular. ${ }^{64}$ Still, such statutes might pass Evans muster, if they are viewed as not depriving gay people of important protections and instead, as, directing state expression in the field of education, where the Supreme Court has said that the state may "inculcate" its vision of the good life. ${ }^{65}$ As in the military cases, courts might defer to parental homophobia (which is often the basis for no promo homo policies in schools) because of the special constitutional status of the parent-child relationship.

A particularly hard case is presented by the federal Defense of Marriage Act ("DOMA"), ${ }^{66}$ which provides that more than 1000 federal statutory provisions involving marriage or spousehood can never be construed to include same-sex couples. If a state recognizes same-sex marriage, DOMA might be vulnerable to Evans attack, because it denies those couples an extraordinary range of rights and obligations normally accorded other married couples, involves the federal government in micromanaging family formation issues traditionally left to the states, and might be characterized, as congressional opponents did, as premature and

63. ARIZ.REV.STAT.ANN. $\S 15-716(C)(1)$ (2) (West Supp. 1998). For other policies to similar effect, see NATIONAL ABORTION AND REPRODUCTIVE RIGHTS ACTION LEAGUE, SEXUAITTY EDUCATION IN AMERICA: A STATE-BY-STATE REVIEW (1995).

64. See Paul Gibson, Gay and Lesbian Youth Suicide, in U.S. DEP'T HeALTH \& HUMaN SERVS., REPORT ON THE SECRETARY's TASK FORCE ON SUICIDE 110 (1989); Donna I. Dennis \& Ruth E. Harlow, Gay Youth and the Right to Education, 4 YALEL. \& POL'Y REv. 446, 448-52 (1986); see also Nabozny v. Podlesny, 92 F.3d 446 (7th Cir. 1996) (school refused to protect gay students from antigay violence, despite repeated pleas).

65. Bethel Sch. Dist No. 403 v. Fraser, 478 U.S. 675, 681 (1986). Schools have authority to "teach by example the shared values of a civilized social order," including broad prohibitions of "lewd, indecent, or offensive speech." Id. at 683.

66. See 28 U.S.C.A. $\S 1738$ C (West Supp. 1998). 
unnecessary legislation seeking to scapegoat gay people. ${ }^{67}$ On the other hand, the arguments made by DOMA supporters generally lacked the hysterical and obsessional flavor of the arguments made by the proponents of the Colorado initiative and of presumptions against gay parental rights. While some supporters spoke of same-sex marriage in apocalyptic terms, ${ }^{68}$ the key supporters made arguments such as this: "Should the law express its neutrality between homosexual and heterosexual relationships? ... Should this Congress tell the children of America that it is a matter of indifference whether they establish families with a partner of the opposite sex or cohabit with someone of the same sex?"69 The gap between the opponents' perceptions and the supporters' arguments exposes deep issues of equal protection law.

The no promo homo rationale of DOMA and other policies is that, even if the state does not consider gay people criminals and is willing to employ openly gay people, the state should be free to express its own republican vision of a happily and heterosexually married society. Rather than compulsory heterosexuality, the intolerant stick-like Hardwick policy, or even the closet-based policy of "don't ask, don't tell," the state ought to be free to adopt a policy of preferred heterosexuality, a more tolerant, carrot-like policy. Senator Dan Coats made this precise distinction in the DOMA debates: "[W] hen we prefer traditional marriage and family in our law, it is not intolerance. Tolerance does not require us to say that all lifestyles are morally equal. ${ }^{.70}$ As Justice Scalia's Evans dissent emphasized, one of Colorado's justifications for the initiative was its signal of the community's belief that heterosexuality is better and more normal than homosexuality as an orientation. Although the Court did not accept this justification as a rational basis for the initiative, it did not dispute or even recognize it either. Thus, another way that Evans could be narrowed is that the state cannot penalize gay people for being out of the closet, and perhaps cannot take away local protections either, but is free to encourage people-especially the proverbial wavering adolescent-to be straight. But surely the state cannot encourage people to feel attraction only for those of their own race. If not, why can the state encourage people to feel attraction only for those of the "opposite" sex?

This question poses one issue Evans ducked and an equally important issue not presented in Evans. As to the first: Should sexual orientation, like race and sex, be viewed as a (quasi) suspect classification requiring heightened scrutiny, whereby an antigay rule must narrowly serve a compelling or substantial state interest? For the reasons advanced by Judge William Norris a decade ago, the Supreme Court's precedents, especially the sex discrimination cases, could justify treating sexual orientation as a suspect or quasi-suspect classification. ${ }^{71}$ The Supreme Court has

67. See, e.g., 142 CONG. REC. S10065-01 (1996) (statement of Sen. Boxer); id. at H6400-01 (1996) (statement of Rep. Schroeder); id. at H1147-03 (1996) (statement of Rep. Frank).

68. See, e.g., id. at H7441-03 (1996) (statement of Rep. Barr); id. at H7480-05 (statement of Rep. Buyer).

69. Id. at H7480-05 (1996) (statement of Rep. Canady). The most eloquent articulation of this idea was by Representative Henry Hyde. See id. at H7480-05.

70. Id. at $\mathrm{H} 10114$ (1996).

71. See Watkins v. United States Army, 847 F.2d 1329 (9th Cir. 1988), withdrawn en banc, 875 F.2d 699 (9th Cir. 1989). 
found sex and other classifications questionable, because they so frequently bear no relation to ability to perform or contribute to society, are typically motivated by stereotypical rather than fact-based thinking, and pervasively affect classes of citizens traditionally subjected to legal disabilities. ${ }^{72}$ Gaylegal history suggests a prima facie case for sexual orientation classifications to fit this mold.

Scientists have found no basis for believing that a homosexual orientation has any correlation with fundamental personal traits such as intelligence, honesty, psychological stability, or ability to cooperate with others. ${ }^{73}$ That sexual orientation classifications almost never serve neutral state goals is illustrated by the rocky history of such classifications. Gender-bending or homosexuality has been used as a classification to determine who can enter the country and become a citizen, what books can be published and read, who can be served in bars, who can be a state employee or be licensed as a teacher, and what movies can be seen-all policies that were hysterically motivated, honored in the breach, and ultimately repealed. ${ }^{74}$ Even the most notable surviving policy, the military exclusion, survives mainly through the grace of the federal courts' extraordinarily deferential approach to military decisionmaking.

Some judges and commentators have urged, unpersuasively, that suspect classifications should be immutable. ${ }^{75}$ This is an unfortunate attempt to say that in

72. See Frontiero v. Richardson, 411 U.S. 677, 685-86 (1973) (plurality opinion). For the Court's similar methodology when evaluating other classifications, see City of Cleburne $v$. Cleburne Living Center, Inc., 473 U.S. 432 (1985) (disabilities); Plyler v. Doe, 457 U.S. 202, 216-17 n.14 (1982) (children of noncitizens); Mathews v. Lucas, 427 U.S. 495, 505 (1976) (nonmarital bith); and Massachusetts Board of Retirement v. Murgia, 427 U.S. 307 (per curiam) (1976) (age).

73. See, e.g., AlfRed C. Kinsey et AL., SeXuAi BeHAVIOR IN THE HuMAN MALE (1948); Alfred C. KInSEy BT AL., SEXUAL BeHavior IN THE Human Female (1953); Evelyn Hooker, Male Homosexuality in the Rorschach, 22 J.PROJECTVE TECHNIQUES 33 (1958); Evelyn Hooker, The Adjustment of the Male Overt Homosexual, 21 J. PROJECTVE TeCHNQUES 18 (1957); Sigmund Freud, Letter to an American Mother (1935) (quoted in ESKRIDGE \& HUNTER, supra note 2, at 143-44). Modern authorities are collected in HOMOSEXUALITY: RESEARCH IMPLICATIONS FOR PUBLIC POLICY (John C. Gonsiorek \& James D. Weinrich eds., 1991), and HOMOSEXUALITY IssUES, supra note 55. For accounts from disciplines traditionally hostile to homosexuality, see KenNeTH Lewes, The Psychoanalytic TheORY of MALE HomoseXuality (1988), and MICHAEL RUSE, HOMOSEXUALITY:APFIIOSOPHICAL INQUIRY (1988). For accounts from different perspectives of sexual and gender variation across time and cultures, see CLELLAN S. FORD \& FrankA. BEACH, PATTERNS OF SEXUAL BEHAVIOR(1951); POSNER, supra note 40, at 291-323; The MaNY Faces of HoMoseXUality: ANTROPOLOGICAL APPROACHES to HoMOSEXUAL BeHavior (Evelyn Blackwood ed., 1986); and Ritualized HoMOSEXUality IN MELANESiA (Gilbert H. Herdt ed., 1984).

74. See Eskridge, supra note 25, at 959-60 (discussing the decline and fall of antigay sodomy and solicitation laws, cross-dressing ordinances, restrictions on assembly and association in bars and college campuses, censorship of literature and erotica, immigration and naturalization policies).

75. The immutability criterion is cogently criticized and rejected for equal protection purposes in Janet Halley, The Politics of the Closet: Towards Equal Protection for Gay, Lesbian, and Bisexual Identity, 36 UCLA L. REV. 915, 923-32 (1989), and Edward Stein, The Relevance of Scientific Research About Sexual Orientation to Lesbian and Gay Rights, in GAY ETHCS: Controversies In OUTING, CIVIL Rights, AND SEXUAL ScLENCE 269 (Timothy Murphy ed., 1994). 
all areas where we have a choice we can make political decisions to reward or punish. Although sex is considered an immutable characteristic, people can conceal their sex, and transsexuals often change their sex. Religion is often mutable and can be easily concealed. Sex, religion, ethnicity, and for many people race (all suspect classifications) are more mutable than nonsupect classifications such as age, intelligence, and most forms of disability. To the extent there is an immutability element in suspect classification law, "a trait [is] effectively immutable if changing it would involve great difficulty, such as requiring a major physical change or a traumatic change of identity." ${ }^{176}$ In any event, scientists agree that sexual orientation is a characteristic formed early in one's life, and the person has little control over this feature of her or his identity. ${ }^{77}$

In deciding which classifications should be suspect, the Supreme Court has sometimes considered the extent to which the classifications have been used to persecute particular groups in American history. ${ }^{78}$ This is always a retrospective inquiry, where persecution is "discovered" only after a group has started to assert itself politically. Gay people fit this pattern perfectly: symbolically excluded in various ways from citizenship and sporadically persecuted, gay people have since the 1960s mobilized as a political group and have made progress in both courts and legislatures. Many old discriminations, and some new ones, remain on the books. They are an irritant to a healthy pluralism and should be subjected to the same sort of critique the Court has shown to sex-based discriminations.

Although sexual orientation fits the traditional criteria for heightened scrutiny, the Court is not eager to add a new category to the list. Indeed, the double standard itself makes less sense today, because antidiscrimination law is choking on a plethora of prejudices. The discourse of prejudice is no longer the province of racism and antisemitism and includes not only sexism and homophobia, but also weightism and lookism, distaste for the disabled, ageism, accent discrimination, stereotypes about people from Appalachia and the South-all of which are legally regulated in many municipalities and some state and federal rules. Prejudice is not only multivocal but universal and even commonplace. The prejudiced person is no longer just the alien Nazi or the cloaked Klan member, but middle-class you and me. This popularization has cost prejudice some of its ability to appall. No longer is prejudice simply pathological or even completely dysfunctional; the bigot's prejudices may help her or him to form a stable identity (narcissistic prejudices), cope with economic marginality (obsessional prejudices), and even feel good about herself or himself (hysterical prejudices). This phenomenon may undermine the Carolene equal protection formulation, which is centrally concerned with prejudice. The pervasiveness of prejudice would render the Carolene justification for judicial activism potentially all-embracing, which would generate strong tensions with constitutional precepts of representative democracy. And as a practical matter the Court cannot monitor all forms of prejudice. It must choose which prejudices to

76. Watkins, 847 F.2d at 1347.

77. See ALAN BELL ET AL., SEXUAL PREFERENCE: ITS DEVELOPMENT IN MEN AND WOMEN 18690 (1981); RICHARD GREEN, THE "Sissy BOY" SYNDROMB AND THE DEVELOPMENT OF HOMOSEXUALITY 370-98 (1987); POSNER, supra note 40, at 101-08.

78. See, e.g., Frontiero v. Richardson, 411 U.S. 677, 685-86 (1973) (plurality opinion). 
monitor because of their bad social consequences, perhaps even recognizing that prejudice will often be rational for individuals but not for society as a whole. This reality might impede the Court from recognizing sexual orientation as a new suspect classification, but not from giving Evans-like teeth to the rational basis approach-nor from deploying the Court's sex discrimination jurisprudence to support homo equality. The second issue raised by DOMA is whether sex-based classifications aimed at excluding gay people must necessarily be subjected to heightened scrutiny even if sexual orientation classifications are not.

\section{THE SEX DisCRIMINATION ARGUMENT FOR HOMO EQUALITY}

Formally, some of the discriminations that most affect gay people are those that classify by sex, rather than sexual orientation. Thus, homosexuals can marry in all states, so long as they marry someone of the opposite sex, for people of the same sex generally cannot marry. Similarly, in six states, anyone gay or straight can engage in sodomy, so long as the partner is of a different-sex. Although such statutory schemes mainly affect gay people, the regulatory classification is sexbased.

In the early 1970 s, a challenge to these sex discriminations took shape from arguments posed by lesbian feminists and male antifeminists, otherwise working at cross-purposes. The Radicalesbians argued that patriarchy was the common enemy of both liberated women and liberated homosexuals, because heterosexuality is a practice that insists upon women's dependence upon men. Synthesizing this philosophy and giving it a memorable tag, Adrienne Rich declared that "compulsory heterosexuality," society's insistence that everyone be heterosexual, is a "profound falseness," a lie that distorts the lives of all women. ${ }^{79}$

At the same time, opponents of the proposed Equal Rights Amendment ("ERA") were articulating the so-called "miscegenation analogy" as a basis for fearing that the ERA would require judicial recognition of same-sex marriage. Professor Paul Freund testified that "if the law must be as undiscriminating toward sex as it is toward race, it would follow that laws outlawing wedlock between members of the same sex would be as invalid as laws forbidding miscegenation. ${ }^{m 80}$ Freund's position was based upon Loving's holding that denying a black-white couple a marriage license is race discrimination, because the classification, the regulatory variable, is the race of one partner. Analogously, denying a female-female couple a marriage license is sex discrimination, because the classification, the regulatory variable, is the sex of one partner. Echoing Freund, ERA opponents in Congress and in state ratification debates argued that the ERA would invalidate state sodomy

79. Rich, supra note 37, at 23-75. For other articulations, see SUZANNE PHARR, HOMOPHOBIA: A WEAPON OF SEXISM (1988); Tr-GRACE ATKINSON, AMAZON ODYSSEY (1974); Anne Koedt, Lesbianism and Feminism, in RADICAL FEMINISM 246 (Anne Koedt et al. eds., 1973); and Radicalesbians, The Woman Identified Woman, in id. at 240. See also AMAZON ExPEDITION: A LESBIAN FEMINIST ANTHOLOGY (Phyllis Birkby et al. eds., 1973); FOR LesBIANS ONLY: A SEPARATIST ANTHOLOGY (Sarah Lucia-Hoagland \& Julia Penelope eds., 1988).

80. 118 CoNG. REC. 9315 (1972) (statement of Sen. Ervin) (quoting Prof. Freund). 
laws and require states to recognize homosexual marriages, a charge disputed by ERA sponsor, Senator Birch Bayh. ${ }^{81}$

Freund's prediction and lesbian feminist hopes did not materialize. Even though almost a third of the states adopted equal rights amendments and the Supreme Court interpreted the equal protection clause to subject sex-based classifications to intermediate scrutiny after 1976, the argument that denying same-sex couples marriage licenses is sex discrimination was decisively rejected in Singer v. Hara ${ }^{82}$ and then was abandoned for a half-generation. In at least one leading case, the sex discrimination argument was used to challenge a sodomy law. Missouri's law only criminalizes same-sex sodomy. The defendant in State $v$. Walsh $h^{83}$ argued that his solicitation of oral sex was illegal only because he had solicited it from a man, not from a woman. ${ }^{84}$ This was rank sex discrimination. Echoing Senator Bayh and Singer, the Missouri Supreme Court held that the statute "applie[d] equally to men and women because it prohibits both classes from engaging in sexual activity with members of their own sex."85

Given the law's uniform rejection of the sex discrimination argument for homo equality, law professors as well as litigators gave up on it-until 1988, when Sylvia Law and Andrew Koppelman revived the argument. ${ }^{86}$ Law linked society's stigmatizing sexual deviance with its insistence upon maintaining women in traditional roles as wife, mother, and man's helper. Koppelman revived Freund's miscegenation analogy, but in support of sodomy repeal and same-sex marriage rather than in opposition to women's rights. The sex discrimination argument for homo equality assumed new relevance with the Hawaii Supreme Court's decision in Baehr v. Lewin that the state's refusal to issue a marriage license to Ninia Baehr and Genora Dancel and two other couples was sex discrimination that requires compelling state justification to survive the state's ERA ${ }^{87}$ In light of Baehr, the argument deserves a fresh look. My look will be critical as well as constructive.

Once they grasp the sex discrimination argument for homo equality, the immediate reaction of lawyers is: This is a trick argument! It has to be wrong! Consider one way of criticizing the argument and its miscegenation analogy. Chief Justice Warren's opinion in Loving emphasized that Virginia's rule against different-race marriages subserved a regime of "White Supremacy," which was antithetical to the core purpose of the Fourteenth Amendment. Singer avoided the miscegenation analogy by limiting Loving to cases where an invidious classification

81. See Note, The Legality of Homosexual Marriage, 82 YALE L.J. 573, 583-84 (1973). Compare 118 CoNG. REC. at 9315 (Sen. Ervin, invoking Freund to oppose ERA), with id. at 9320-9321 (Sen. Bayh, disputing Freund's analysis).

82. 522 P.2d 1187 (Wash. Ct. App. 1974).

83. 713 S.W.2d 508 (Mo. 1986).

84. See id. at 510 .

85. Id. at 510 .

86. Andrew Koppelman, Why Discrimination Against Lesbians and Gay Men Is Sex Discrimination, 69 N.Y.U. L. REV. 197 (1994); Sylvia Law, Homosexuality and the Social Meaning of Gender, 1988 Wis. L. REV. 187; Andrew Koppelman, Note, The Miscegenation Analogy: Sodomy Law as Sex Discrimination, 98 YALE L.J. 145 (1988).

87. 852 P.2d 44, 65 (Haw. 1993), on remand sub nom. Baehr v. Miike, CIV. No. 91-1394, 1996 WL 694235 (Haw. Cir. Ct. Dec. 3, 1996) (on appeal as of May 1, 1999). 
is used to suppress a group whose identity is defined by that classification. ${ }^{88} \mathrm{Baehr}$, which rejected Singer, may not be a sex discrimination case in the same way Loving is a race discrimination case. The classification in Baehr is sex, but the class being disadvantaged is defined by sexual orientation (gay people) and not by sex (women). The philosophy that justifies their disadvantage is compulsory heterosexuality, not simple sexism. Table 1 maps the differences among the cases as critics might read them.

\begin{tabular}{|c|c|c|c|}
\hline & Classification & $\begin{array}{c}\text { Disadvantaged } \\
\text { Class }\end{array}$ & $\begin{array}{c}\text { Philosophical } \\
\text { Target }\end{array}$ \\
\hline Loving & Race & Racial Minorities & Racism \\
\hline ERA & Sex & Women & Sexism \\
\hline Baehr & Sex & Sexual Orientation & $\begin{array}{c}\text { Compulsory } \\
\text { Heterosexuality }\end{array}$ \\
\hline
\end{tabular}

Note immediately that the middle column is misleading. In Loving, the disadvantaged class is "miscegenosexuals," Sam Marcosson's term for people who fall in love with someone of another race. ${ }^{89}$ Many African Americans did not favor different-race marriage in 1967, and many disfavor it now. Racial minorities were disadvantaged by the classification only by reasoning from the underlying ideology, racism. Hence, the middle column in Loving reflects an indirect reasoning process rather than direct harm. The ERA line must be qualified in the same way. In Craig $v$. Boren, the case that established sex is a quasi-suspect classification, the disadvantaged group was eighteen- to twenty-one year-old males who were denied the right to buy low-alcohol beer that eighteen to twenty-one year-old females enjoyed. Subjecting the sex-based classification to heightened scrutiny, the Supreme Court emphasized that sex-based classifications ostensibly benefiting women are just as objectionable as those ostensibly benefiting men when they reflect "outdated misconceptions concerning the role of females in the home rather than in the 'marketplace and world of ideas." $"$ When traditional gender stereotypes animate a sex-based classification, women as a group suffer, at least indirectly. Again, the second column only reflects indirect harm, deriving from the underlying philosophy (sexism) and not from the classification in a particular case (women can buy drinks earlier than men).

To make the miscegenation analogy complete, however, one must show that denying a same-sex couple a marriage license subserves a regime of sexism which is antithetical to the core purpose of a state ERA or of the Fourteenth Amendment

88. See Singer v. Hara, 522 P.2d 1187, 1191-92 (Wash. Ct. App. 1974).

89. Samuel Marcosson, Harassment on the Basis of Sexual Orientation: A Claim of Sex Discrimination Under Title VII, 81 GEO. L.J. 1, 6 (1992).

90. Craig v. Boren, 429 U.S. 190, 198-99 (1976) (quoting Stanton v. Stanton, 421 U.S. 7 (1975)). 
as interpreted in Craig. If such a showing could be made, then Baehr would fit the Craig model and would be perfectly analogous to Loving, as reflected in Revised Table 1. Parentheses are used for the middle column, in order to suggest that the disadvantaged class is based upon inference from the underlying philosophy.

\begin{tabular}{|c|c|c|c|}
\hline \multicolumn{4}{|c|}{ REVISED TABLE 1 } \\
\hline Loving & Classification & $\begin{array}{c}\text { Disadvantaged } \\
\text { Class }\end{array}$ & $\begin{array}{c}\text { Philosophical } \\
\text { Target }\end{array}$ \\
\hline Craig & Sex & $\begin{array}{c}\text { Miscegenosexuals } \\
\text { (Racial Minorities) }\end{array}$ & Racism \\
\hline Baehr & Sex & $\begin{array}{c}\text { 18- to 21-Year-Old } \\
\text { Males (Women) }\end{array}$ & Sexism \\
\hline
\end{tabular}

Under Revised Table 1, Baehr would be the same as Craig and analytically indistinguishable from Loving.

The same kind of argument could also be made against same-sex only sodomy laws. Following Singer, the Missouri court in Walsh held that, so long as male-male and female-female sodomy were treated the same, there was no sex discrimination." This reasoning was rejected in the race context. In Pace $v$. Alabama ${ }^{92}$ the Supreme Court upheld a law criminalizing different-race sex on the ground that because each race was treated the same there was no race discrimination. But Pace was overruled in McLaughlin v. Florida ${ }^{93}$ where the Court struck down a statute prohibiting lewd cohabitation between different-race couples only. The defendants, a black-white couple, would not have violated the law if they had been a cohabiting white-white couple. The Supreme Court held this was race discrimination, because the classification, the regulatory variable, was the race of one of the partners. ${ }^{94}$ Under the reasoning of McLaughlin, Walsh is as incorrect as Singer. Table 2 captures the race analogy for same-sex sodomy laws.

91. State v. Walsh, 713 S.W.2d 508, 510 (Mo. 1986) (en banc).

92. 106 U.S. 583 (1883).

93. 379 U.S. 184 (1967).

94. See id. at 195. 


\begin{tabular}{|c|c|c|c|}
\hline & Classification & $\begin{array}{c}\text { Disadvantaged } \\
\text { Class }\end{array}$ & $\begin{array}{c}\text { Philosophical } \\
\text { Target }\end{array}$ \\
\hline McLaughlin & Race & $\begin{array}{c}\text { Miscegenosexuals } \\
\text { (Racial Minorities) }\end{array}$ & Racism \\
\hline Craig & Sex & $\begin{array}{c}\text { 18-to 21-Year-Old } \\
\text { Males (Women) }\end{array}$ & Sexism \\
\hline Walsh & Sex & $\begin{array}{c}\text { Gay Couples } \\
\text { (Women) }\end{array}$ & Sexism \\
\hline
\end{tabular}

The remainder of this Part will consider the relationship between these antigay exclusions and sexism along lines of constitutional doctrine, the (legal) history of sexuality and gender, and the theory of multivocal prejudices.

\section{A. Compulsory Procreation and Rigid Gender Roles}

A majority of the Supreme Court now seems committed to the proposition that any classification based on sex that insists on rigid gender roles requires an exceedingly persuasive state justification under the Equal Protection Clause. As Justice Ruth Bader Ginsburg put it for the Court in the United States v. Virginia, the VMI case ("VMI"), when the state controls "gates to opportunity," it "may not exclude qualified individuals based on "fixed notions concerning the roles and abilities of males and females." J95 Justice John Paul Stevens has added: "Discrimination that is 'merely the accidental byproduct of a traditional way of thinking about females' is unacceptable." classifications subserving traditional gender roles would likely extend to the judiciaries of any state (such as Hawaii) having an equal rights amendment to its state constitution, and to most other states as well.

American law regulating sexuality and sexual unions has traditionally been gendered, and in a very simple way: women cannot have sex outside of procreative penis-vaginal sex in marriage to a man, and men cannot have sex outside of procreative penile-vaginal sex in marriage to a woman. State law in the colonial

95. United States v. Virginia, 518 U.S. 515, 541 (1996) (quoting Mississippi Univ. for Women v. Hogan, 458 U.S. 718, 725 (1982)); see Miller v. Albright, 118 S. Ct. 1428, 1445-46 (1998) (O'Connor, J., concurring in the judgment, joined by Kennedy, J.); id. at 1449-55 (Ginsburg, J., dissenting, joined by Breyer and Souter, JJ.).

- 96. Miller, 118 S. Ct. at 1441 (quoting Califano v. Goldfarb, 430 U.S. 199, 223 (1977) (Stevens, J., concurring in the judgment)). 
era ${ }^{97}$ and in the nineteenth century ${ }^{98}$ made it a serious crime for unmarried men and women to have penile-vaginal sex (fornication) or anal sex (sodomy); marriage rendered any kind of penile-vaginal sex legal and indeed rendered forcible sex immune from rape laws; the sexual crimes a married man could commit were penile-vaginal sex with a woman (adultery) or girl (seduction) not his wife, or anal sex (sodomy) with his wife, another woman or girl, or a male. Once contraception, abortion, and oral sex came to be more commonly practiced, as means of sexual pleasure without the risk of pregnancy, states adopted new laws making those practices illegal as well (1850-1920).$^{99}$ This regime of criminal laws was gendered to the core, directly reflecting the Roman Catholic and Puritan natural law philosophy: Sex is bad unless practiced in a procreative way (penis in a vagina) within the institution of male-female marriage; the role of a woman is to receive the sperm of a man, become impregnated, and bear and raise the child; the role of the man is to impregnate the woman and rule over the household formed as children are borne.

This century has seen a relaxation of the natural law regime. Many of its gendered features have been repealed or invalidated, including the complete exemption for rapes within marriage, the wife's lack of independent legal rights, and prohibitions of abortion and the distribution of contraceptives. Some of the antisex features have been repealed in some but not all states, including the crimes of fornication, adultery, and sodomy. ${ }^{100}$ Although state law no longer makes procreation the linchpin of marriage, it does continue to refuse to recognize marriages between two women or two men, a discrimination based on the sex of one of the partners that "exclude[s] qualified individuals based on "fixed notions concerning the roles and abilities of males and females" $" 101$ or, at the very least, is a "byproduct of a traditional way of thinking about females." 102 Sodomy laws indirectly reflect the same regime, as they center sexual expression around pregnancy-based penilevaginal intercourse; laws prohibiting only same-sex sodomy directly instantiate a gendered regime whereby women can only have sex with men. In short, these sexbased classifications strongly originated in and continue to serve the kind of rigid gender stereotyping that the Supreme Court criticized in $V M I$ and other cases. Indeed, the policy against allowing two women to marry is driven by a more obvious insistence upon traditional gender roles than the policy of allowing

97. For colonial era documents, see JoNATHAN NED KATZ, GAY/LeSBIAN ALMANAC 23-133 (1983).

98. For mid-nineteenth century state criminal law relating to sex, see, for example, 2 JoEL PRENTISS BISHOP, COMMENTARIES ON THB CRIMINAL LAW § 1127 (1858); 2 JOSEPH CHITTY, A PRACTICAL TREATISE ONCRIMINAL LAW 48-50 (5th amended ed. 1847); and Francis WHARTON, A TREATISE ON CRIMINAL LAW OF THE UNITED STATES § 2267 (1852).

99. This process is traced in Reva Siegel, Reasoning from the Body: A Historical Perspective on Abortion Regulation and Questions of Equal Protection, 44 STAN. L. REV. 261 (1992) (antiabortion legislation, 1850 onward), and Eskridge, supra note 28 (criminalization of oral sex, 18791921).

100. For a relatively current survey of the various rules in place, see RICHARD A. POSNER \& KATHARINE B. SLBAUGH, A GUIDE TO AMERICA's SEX LAWS (1996).

101. United States v. Virginia, 518 U.S. 515, 541 (1996) (quoting Mississippi Univ. for Women v. Hogan, 458 U.S. 718, 725 (1982)).

102. Califano v. Goldfarb, 430 U.S. 199, 223 (1977). 
eighteen-year-old women but not men to buy beer that was invalidated in Craig. The requirements of Tables 1 (as revised) and 2 would appear to be satisfied.

The thoughtful reader might well believe that the syllogism is still too literal a reading of the Court's precedents to bring sex-based marriage and sodomy rules within respectable sex discrimination law. A central doctrinal objection might be grounded upon the Court's recognition that "inherent differences" between men and women can justify sex-based rules. ${ }^{103}$ Indeed, the argument that has usually prevailed in the same-sex marriage challenges is that marriage naturally and inevitably involves a man and a woman, because their biological differences make them congenial opposites that nonetheless attract. The Minnesota Supreme Court in Baker v. Nelson, ${ }^{104}$ the first reported decision rejecting a legal challenge to the same-sex marriage bar, began its constitutional discussion with the premise that "[t]he institution of marriage as a union of man and woman, uniquely involving the procreation and rearing of children ... is as old as the book of Genesis."10s Baker was followed by every court to address the issue, until Baehr. Yet its factual assertions are explicitly gendered, and factually erroneous besides. ${ }^{106}$

The natural law conception of marriage that Baker adopted is itself sexist, as it practically and by some accounts necessarily relegates women to traditional roles stereotypically assigned to women: wife, mother, homemaker. These gendered roles are precisely the ones reflected in the law's traditional persecution of lesbians, where the standard reproach has been that women should stay in their place-in the home, at the side of a man. Allowing two women to get married would undermine the gendered nature of marriage, because at least one of the women (and usually both) would assume the traditional male role of breadwinner. Thus, when Ninia Baehr and Genora Dancel were denied a marriage license by Hawaii, the State was reasserting traditional gender roles. When the Court has invoked the inherent differences doctrine to acquiesce in a sex-based classification, it has generally been a classification which opens up new opportunities for or benefits women. According to the $V M I$ decision, the doctrine is not applicable to rules that were adopted "for denigration of the members of either sex or for artificial constraints on an individual's opportunity."107

A deeper, yet perhaps more obvious, objection is that sexuality and gender are simply different. Gaylaw should not leech off of sex discrimination jurisprudence.

103. Virginia, 518 U.S. at 534 (citing cases).

104. 191 N.W.2d 185 (Minn. 1971).

105. Id. at 186. For cases citing Baker as authority, see Jones v. Hallahan, 501 S.W.2d 588, 589 (Ky. 1973), and Singer v. Hara, 522 P.2d 1187, 1192 (Wash. Ct. App. 1974). As Baker's reference to Genesis reflects, judges rejecting same-sex marriage have also relied upon the nation's religious heritage. See Dean v. District of Columbia, No. 90-13892, 1992 WL 685364 (D.C. Super. Ct. June 2, 1992) (quoting passages from Genesis, Deuteronomy, Matthew, and Ephesians to support its holding that "societal recognition that it takes a man and a woman to form a marital relationship is older . . than Christianity itself"), aff"d, 653 A.2d 307 (D.C. 1995); Adams v. Howerton, 486 F. Supp. 1119, 1123 (C.D. Cal. 1982), aff'd, 673 F.2d 1036 (9th Cir. 1983).

106. See William N. EsKridge, JR, The CASE FOR SAME-SeX Marriage: From SeXUal LBERTY TO CIVILIZED COMMITMENT ch. 2 (1996).

107. Virginia, 518 U.S. at 534 (citing cases). Possible exceptions include proof of paternity cases and the full statutory rape case. After $V M I$ and Miller $v$. Albright, it is not clear that either line of cases retains viability. 
Why should gay men benefit from a jurisprudence designed to put women on an equal plane with men? Admittedly, the sex discrimination argument for homo equality has a transvestic quality, dressing up gay rights in sex equality garb. But, as feminist and lesbian-feminist writers have long maintained, antihomosexual attitudes are connected with attitudes sequestering women in traditional gender roles.

Social science studies of male homophobia emphasize a correlation between antihomosexual feelings and "a belief in the traditional family ideology, i.e., dominant father, submissive mother, and obedient children," as well as "traditional beliefs about women, e.g., that it is worse for a woman to tell dirty jokes than it is for a man." ${ }^{\text {"108 }} \mathrm{A}$ few studies claim a causal link:" "[A] major determinant of negative attitudes toward homosexuality is the need to keep males masculine and females feminine, that is, to avoid sex-role confusion." 109 The Kinsey Institute published a thorough survey of Americans' attitudes about sex and sexuality, using sophisticated statistical analyses in 1989. These researchers found that one variable significantly linked to antihomosexual feelings was the respondents' own fears and anxieties about the opposite sex. The researchers believe that people who feel threatened by the opposite sex will be hostile to homosexuality as a defense mechanism, displacing an identity-shattering fear onto a socially safe object (gender-bending queers). "Accordingly, we may condemn the homosexual in order to reduce sex role confusion."'110 These empirical points must, however, be understood against the backdrop of the complicated history, including the legal history, of sexuality and gender role in the last century or so.

\section{B. Historical Connections Between Gender Stereotyping and Compulsory Heterosexuality}

As I have shown above, traditional natural law regulation of sexuality was closely tied to procreative penile-vaginal intercourse within marriage. The historical process by which that regime eroded in the face of feminist demands generated both

108. Stephen Morin \& Ellen Garfinkle, Male Homophobia, 34 J. Soc. IssuEs, 29,31 (1978); see Mary Laner \& Roy Laner, Sexual Preference or Personal Style? Why Lesbians Are Disliked, 5 J. Homosexuality 339 (1980); Mary Laner \& Roy Laner, Personal Style or Sexual Preference? Why Gay Men Are Disliked, 9 INT'L REv. MOD. SOC'Y 215 (1979); see also Koppelman, supra note 86, at 238 \& n.157 (citing numerous studies discussing the "correlation between conventional expectations about gender roles and hostility toward homosexuals").

109. A.P. MacDonald \& Richard Games, Some Characteristics of Those Who Hold Positive and Negative Attitudes Toward Homosexuals, 1 J. HoMOSEXUALITY 9, 19 (1974); see also Kathryn N. Black \& Michael R. Stevenson, The Relationship of Self-Reported Sex-Role Characteristics and Attitudes Toward Homosexuality, in BASHERS, BAITERS AND BIGOTS: HOMOPHOBIA IN AMERICAN SOCIETY 83 (John DeCecco ed., 1985).

110. ALBERT D. KLASSEN ET AL., SEX AND MORALITY IN THR U.S.: AN EMPIRICAL ENQUTRY UNDER THEAUSPICES OF THB KINSEY INSTTTUTB 241 (1989) (quoting A.P. MacDonald, Jr. et al., Attitudes Toward Homosexuality: Preservation of SexMorality or the Double Standard? $40 \mathrm{~J}$. CONSULTING \& CLINICAL PsYCH. 161 (1973)). 
the modern idea of gender role and the modern conception of the homosexual. ${ }^{111}$ As an increasing number of women became socially and economically independent of men in the nineteenth century, bourgeois male culture reacted, directly, by suppressing women's aspirations and controlling women's bodies and, indirectly, by creating "the homosexual" as an object of special scorn. Setting up the effeminate man as the antithesis of manhood, men were reassured of their own superior virility. Setting up the lesbian as an object to be feared, men asserted their central role in women's lives. The creation of homosexuals as a despised class reinforced the gender norms of male superiority and control. In short, there is a historical as well as logical connection between compulsory gender binarism, the idea that men must be masculine and women must be feminine, and compulsory heterosexuality, the idea that sexuality must consist of a man having sex with a woman. Indeed, the idea of rigid gender lines logically and historically preceded the idea of compulsory heterosexuality.

Much of the new discourse of gender and sexuality was medical in nature. The leading sexologist of the late nineteenth century was Richard von Krafft-Ebing, whose Psychopathia Sexualis rearticulated old natural law ideas in new medicalized terms of gender binarism. His starting premise was that men are sexually aggressive, sensual, and public-oriented, while women are sexually passive, spiritual, and family-oriented. ${ }^{112} \mathrm{Krafft-Ebing's} \mathrm{project} \mathrm{was} \mathrm{to} \mathrm{catalogue}$ sexual "pathologies," or dysfunctions, including "antipathic sexuality." There were several stages of antipathic sexuality: (1) the physically normal person who has homosexual tendencies, whereby she or he is attracted to those of her or his own sex but plays a role appropriate to her or his gender (submissive female, insertive male); (2) the psychic invert, who assumes the psychological characteristics of the opposite sex and prefers to play an inverted role in intercourse (the inverted male enjoys submission, the inverted female aggression); and (3) the physical invert, whose physiology resembles that of the opposite sex and who can only play an inverted role in intercourse (probably hermaphrodites and other intersexuals). ${ }^{113}$ The pathology of "sexual inversion" was the individual's departure from traditional gender roles. Havelock Ellis's Sexual Inversion, which popularized these ideas in the English-speaking world, explicitly made a connection between women's increased freedom and homosexuality: Not only was the lesbian psychically gender-

111. The historiography that has most influenced my thinking in what follows is, especially, CARROLl SMITH-ROSENBERG, DISORDERLY CONDUCT: VISIONS OF GENDER IN VICTORIAN AMRRICA (1985); John D'Emilio, Capitalism and Gay Identity, in POWERS OF DESRE: THE PolITICS OF SEXUALITY 100 (Ann Snitow et al. eds., 1983); E. ANTHONY ROTUNDO, AMBRICAN MANHOOD: TRANSFORMATIONS IN MASCULINTTY FROM THE REVOLUTION TO THE MODERN ERA (1993); and LIILIAN FADERMAN, SURPASSING THE LOVE OF MEN: ROMANTIC FRIENDSHIP AND LOVE BETWEen WOMEN FROM THE RENAISSANCE TO THB PRESENT (1981). For earlier developments along these lines in Europe, see Randolph Trumbach, Gender and the Homosexual Role in Modem Western Culture: The 18th and 19th Centuries Compared, in HoMOSEXUALITY, WHICH HOMOSEXUALITYY? 149, 153 (Dennis Altman et al. eds., 1989).

112. Richard VON KRAFFT-EBING, PSYCHOPATHIA SEXUALIS, WITH SPECial REFERENCE TO THE ANTIPATHIC SEXUAL INSTINCT: A MEDICO-FoRENSIC STUDY 14 (F.J. Rebman trans., Physicians \& Surgeons Book Co. 1931) (1899), quoted and contextualized in ESKRIDGE \& HUNTER, supra note 2, at 136-41.

113. See KRAFFT-EBING, supra note 112 , at 54-55, 382-83. 
inverting, but feminism was contributing to sexual inversion by encouraging women to go out in the world. ${ }^{114}$ Reflecting a stronger ongoing influence of natural law thinking, American doctors were even more dogmatic about the connection between gender-bending and sexual inversion than Krafft-Ebing and Ellis. ${ }^{115}$

American law reflected and may have contributed to the many-layered connection between gender inversion and what came to be known as sexual deviance, even before the sexologists developed their theories. The best examples are the pervasive laws against disguise and cross-dressing. ${ }^{116}$ Although the earliest laws, enacted in the period surrounding the Civil War, were aimed in part at gender fraud, women passing as men, they also struck directly at gender inversion, men as well as women abandoning their gender costumes. In a final regulatory move, such laws came to be enforced to regulate sexual inversion before the turn of the century. In cities such as Boston, Nashville, New York, and San Francisco, the female impersonator and mannish lesbian were put in jail under disguise statutes, not because anyone was fooled, but because their costumes rejected their gender role and reflected their deviant sexual tastes, which contemporaries viewed as a single crime against bourgeois male society. Famous cross-dressing criminals included Jeanne Bonnet, the San Francisco cross-dresser who organized a band of man-renouncing prostitutes in the 1870s; Alice Mitchell, a Memphis socialite who loved another woman and proposed to dress as a man to obtain a license to marry her in 1892; Ralph Werther, a female impersonator who cavorted on the streets of New York in the 1880s and 1890s; Elvira Mugarietta, the open cross-dresser of the 1890s who completely masqueraded as a man after 1900; and the fairies of Newport, crossdressing sailors who tricked with male trade and with one another during World War I-all came into conflict with the law's increasing concern with genderbending. ${ }^{117}$ In the cases of Mitchell and the Newport sailors, their legal downfalls were extensively chronicled by the press and galvanized citizens throughout the country with the scandal, and for some the allure, of gender/sexual deviance.

The cross-dressing laws were only the most explicit legal enforcement of gender binarism. More important, if indirect, enforcement came through antiprostitution

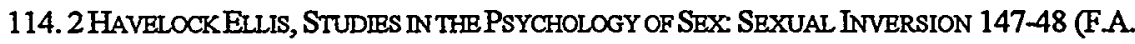
Davis Co. 1913) (1897).

115. See GEORGEM. BEARD, SEXUAL NEURASTHENIA: Its HYGIBNE, CAUSES, SYMPTOMS, AND TREATMENT (2d ed. 1886); G. Frank Lydston, Clinical Lecture: Sexual Perversion, Satyriasis and Nymphomania, 61 MED. \& SURGICAI REP. 253 (1889). For other early examples, see JONATHAN NeD KATZ, GAY/LESBIAN ALMANAC: A NEW DOCUMBNTARY (1983); and George Chauncey, Jr., From Sexual Inversion to Homosexuality: Medicine and the Changing Conceptualization of Female Deviance, 58-59 SALMAGUNDI 114 (1982/83), reprinted in HOMOSEXUALITY: SACRIIEGE, VISION, PolITICS (Robert Boyers \& George Steiner eds., 1982-83).

116. See Eskridge, American Regulation, supra note 48, at 1040-43; Nan D. Hunter, Gender Disguise and the Law (1989) (unpublished manuscript, on file with author).

117. See EARL LIND (Ralph Werther-Jenie June), AUTOBIOGRAPHY OF AN ANDROGYNE (Arno Press 1975) (1918); LAWRENCE R. MURPHY, PERVERTS BY OFFICLAL ORDER: THE CAMPAIGN Aganst HoMOSEXUALS BY 'THE UNTTD STATES NAVY (1988); LOUIS G. SULLIVAN, FroM FEMALE TO MALE: THE LIFE OF JACK B. GaRLAND (1990); Lisa Duggan, The Trials of Alice Mitchell: Sensationalism, Sexology, and the Lesbian Subject in Turn-of-the-Century America, 18 SIGNS 791 (1993). 
and sodomy laws that were dynamically applied to sexual inverts. ${ }^{118}$ In New York City, the police and magistrates fashioned out of the prostitution cases a separate category for "disorderly conduct-degeneracy," applicable to male inverts. The regulatory category appropriated Kraff-Ebing's terminology for sexual inverts and was apparently enforced primarily against female impersonators, like Werther. The relationship between the prostitute and the sexual invert, suggested both in the laws and their police enforcement, lay in their violation of rigid gender roles: The entrepreneurial, sexualized prostitute and the mannish lesbian violated women's role as passive and nurturing; the male invert, sensual and sexually receptive, violated men's role as aggressive and sexually active. The period between the Civil War and World War I, when same-sex intimacy became regulated, is also the period when the states adopted statutes regulating women's ability to plan their childbearing through contraception and abortion and to work outside the home and in jobs on a par with men. ${ }^{119}$ Boưrgeois male assertion of legal control over their wives' bodies and potential careers was followed by their assertion of control over other women and men who violated the cult of "true womanhood" and its gender lines: prostitutes, fairies, and lesbians.

After 1880, for the first time in American history, sodomy laws were enforced in northern, midwestern, and some western cities against more than one or two people a year. ${ }^{120}$ The pattern of enforcement changed in response to the new regulatory discourse about degeneracy and inversion. Where virtually all of the reported pre1900 sodomy cases involved male aggression (anal sex, akin to rape) against a more vulnerable person or animal, many of the post-1900 cases involved consensual sex (oral sex) between two adults, typically two men. ${ }^{121}$ When the state imprisoned a man for soliciting or giving oral sex to another man, the state was no longer punishing something akin to rape, but was punishing the gender inversion of a man giving pleasure to another man. The Newport investigations fully reveal the perceived connection between gender inversion and homosexuality by the end of World War I. After the war, just as oral sex was booming among married couples, it was more heavily policed than ever before among same-sex couples. Compulsory heterosexuality became the policy, and it reflected a decisive shift from disgusting acts to departure from gender role as the focus of regulatory concern. Oral sex between husband and wife was no longer considered criminally disgusting; between two consenting male adults, it could get you life in prison or, starting in the 1930 s, in a mental hospital.

The cultural impulse to reaffirm traditional gender lines is only a fragment of the story, however. Fear of uncontrolled (male) sexuality, not just insistence on strict gender binarism, played an important role in the law's harsher focus on same-sex intimacy. The shift in regulatory emphasis was from the psychic or physical "invert" and "degenerate" to the "homosexual" and the sexual "pervert."122 This reflected

118. See Eskridge, American Regulation, supra note 48, at 1025-32, 1043-45.

119. See Siegel, supra note 99, at 282.

120. See Eskridge, American Regulation, supra note 48, at 1110-11 \& app.1.

121. See Eskridge, supra note 28.

122. See Estelle Freedman, "Uncontrolled Desires": The Response to the Sexual Psychopath, 1920-1960, 74 J. AM. Hist. 83, 94, 103 (1987). 
an intellectual shift from the philosophy of Krafft-Ebing to the philosophy of Sigmund Freud or, more precisely, to the weird synthesis of their theories accomplished by the American Freudians in the 1910 s and 1920 s. $^{123}$ Although Freud's theories reflect traditional gender concepts, their focus was the development of "normal" sexuality, a critical part of one's personal identity. Influenced by puritanical sex negativity, the American Freudians demonized deviance from the norm, and American law treated deviants as sexual psychopaths, persons whose impaired Freudian egos could not control their dangerous sexual libidos. The "predatory homosexual" and the "vampire lesbian," foreshadowed in American culture by World War I, were prominent in the generation afterward.

This Americanized version of Freud inspired prosecutors, legislators, policemen, and judges from the 1920s onward. An early expression of this ideology, by an Ohio judge, described "sexual perverts" as "wild ferocious animals." Justifying the relaxation of the traditional rule against allowing evidence of other crimes in a criminal prosecution, the judge said,

It is more or less a matter of common knowledge, among those who have made a study of sexual perversion as it manifests itself in human degenerates, that each sexual pervert follows some habitual, unnatural method of gratifying his perverted passion. It may be unnatural commerce with one class of beasts or another class of beasts; it may be by one mature male with another mature male; and it may be, which is to-day [sic] of too frequent occurrence, a dynamic sexual commerce with little boys or little girls. ${ }^{124}$

As this excerpt makes clear, antihomosexual fears were linked to concerns about child molestation, the greatest possible calamity in the Freudian universe, because it was sure to unhinge the child's progression to normal heterosexuality. An Oklahoma judge later put it this way:

"Exposure to the sex deviate may have a decisive and harmful effect upon a
child's development of a normal sex life as an adult. Despite their differences of
opinion, students of homosexuality seem to agree that exposure during
adolescence may be the precipitating factor in the aduit development of the
homosexual or the Lesbian. The law must make it possible to take effective
action against twisted adults who use children and minors as sexual objects."

Antihomosexual policies developed during and after World War II, especially the military exclusion, were responsive to multiple anxieties. This complexity is vividly reflected in the War Department Inspector General's investigation of the Women's Army Corps training camp at Fort Oglethorpe in the spring of 1944 . The investigators were unwilling to refer women to treatment as lesbians unless they were persuaded that the women were homosexual in orientation and had engaged in "unnatural acts" with one another and exhibited cross-gender characteristics,

123. See 1 Nathan G. Hale, JR, Freud and the Americans: The Beginnings of PSYCHOANALYSIS IN THE UNITED STATES, 1876-1917 (1971), for a detailed account of the American Freudians.

124. Barnett v. State, 135 N.E. 647,649 (Ohio 1922).

125. Berryman v. State, 283 P.2d 558, 565 n.l (Okla. Crim. App. 1955) (quoting MorRIS PLOSCOWE, SEXAND THE LAW (1951)). 
especially dressing or passing as a man. ${ }^{126}$ During the witch-hunt period from 1947 to 1961 , lesbians as well as gay men were increasingly stigmatized as predatory psychopaths, even as the gender inversion charge remained a powerful one. The federal government's postwar exclusion of gay people from the civil service as well as the armed service, emphasized the tendency of "homosexuals and other sex perverts" to "entice normal individuals to engage in perverted practices," as the 1950 Hoey Subcommittee report put it. ${ }^{127}$ Similar characterizations were made in official federal justifications for excluding gay people, coded as "sexual psychopaths," from entering the country and from becoming U.S. citizens. ${ }^{128}$ On the other hand, federal authorities continued to emphasize gender deviance as well, particularly for women. Military training lectures in the early 1950s told female recruits that "[ $t]$ he Creator has endowed the bodies of women with the noble mission of motherhood and the bringing of human life into the world. Any woman who violates this great trust by participating in homosexuality not only degrades herself socially but also destroys the purpose for which God created her." Women were warned that they "may ruin [their] chances for a happy marriage. . . If a woman gets entangled in homosexuality and is given an undesirable discharge or a dishonorable discharge from the Navy, she finds herself cut off from acceptable relationships with men and the companionship of normal women."129

The dual themes of gender inversion and sexual predation were also apparent in the state manias and panics, such as the Boys of Boise panic in 1956-1957, the Miami Hurricane of 1953-1954, and the New York and San Francisco Bar Wars of 1960-1961. ${ }^{130}$ For example, when Miami began its purge of "sex perverts and degenerates" in 1953, local police officials specifically invoked images of male "girlishness" and child molestation. "We intend to continue to harass those men who affect female mannerisms in public places and let them know in no uncertain terms that they are unwelcome on Miami Beach," said the police chief. ${ }^{131}$ During the antihomosexual campaign, Miami adopted new ordinances making it a crime for "female impersonators" to perform in the city (1952), "lesbians and homosexuals" to congregate (1954), or for any person to cross-dress or engage in lewd behavior

126. See Report of Lieutenant Colonel Birge Holt and Captain Ruby Herman to the Acting Inspector General (July 29, 1944) (appendix of testimony of Dr. Alice Rost), available at National Archives, Suitland, Maryland, Record Group 159 (office of the Army Inspector General), File No. 333.9 (Third WAC Training Center). The Report is described and quoted in Eskridge, American Regulation, supra note 48, at 1092-93.

127. STAFF OF SUBCOMM. ONINVESTIGATIONS OF THE SENATE COMM. ON EXXPENDITURES IN THE EXICUTIVE DEP'TS, 81ST CONG., INTERIM REPORT ON EMPLOYMENT OF HOMOSEXUALS AND OTHER SEXPERVERTS IN GOVRRNMENT, S. Doc. No. 81-241, at 4 (1950).

128. See H.R. REP. No. 82-1365, at 24 (1950), reprinted in 1952 U.S.C.C.A.N. 1653, 1701; S. REP. No. 82-1137, at 9 (1950).

129. Report of the Board Appointed to Prepare and Submit Recommendations to the Secretary of the Navy for the Revision of Policies, Procedures and Directives Dealing with Homosexuals, app. 23 (Chaplain's Presentation (WAVE Recruits)) at 2 (Dec. 21, 1956 to Mar. 15, 1957) (unpublished report, on file with author).

130. See generally Eskridge, Privacy Jurisprudence, supra note 48, at 724-33.

131. Bureau of Pub. Info., Miami Junks the Constitution, ONE, INC., Jan. 1954, at 16, 19. For similar rhetoric later in the antihomosexual campaign, see Lyn Pedersen, Miami Hurricane, ONE, INC., Nov. 1954, at 6. 
(1956). ${ }^{132}$ By the late 1950s, however, when the Florida Legislation Investigating Committee began its inquiries into homosexuality, the chief concern was predation. As the committee said in its 1959 report, "The greatest danger of a homosexual is his or her recruitment of other people into such practices."133 In other states, most notably California, the image of the predatory female or male homosexual was most galvanizing in the field of public education.

After 1961, the terror which put homosexuals constantly on the defensive slowly turned to a thermidor, during which gay people were able to reclaim many of the rights of citizenship. The effect of women's liberation on gay liberation was complicated. On the one hand, the acceptance, even if partial, of equal rights for women contributed to homo equality as well. Discriminated against first because they were women and then because they were gay women, lesbians benefitted directly from any policy protecting against sex discrimination. Laws against crossdressing were directly undermined by cultural acceptance of women's freedom to wear comfortable men's clothing, which contributed to greater toleration for men wearing dresses. The women's movement also facilitated a dramatic post-1969 reconfiguration of sodomy laws: At the same time gays were protesting state harassment of same-sex intimacy, women were insisting upon more vigorous state attention to female child molestation and rape; the result was a revolution in sodomy law enforcement, from an emphasis on same-sex male intimacy, to an emphasis on male-female rape or child molestation. Most of the connections were less direct. Cities and states with populations favoring equality for women were not only more likely to decriminalize same-sex intimacy in the 1960s and 1970s, but also much more likely to adopt laws prohibiting sexual orientation discrimination in the 1970s and 1980. ${ }^{134}$

On the other hand, antihomosexual arguments continued to be made, with unabated passion but with new rhetorical emphases. The feminist movement gradually discredited explicit appeals to rigid gender roles. Consequently, public antigay rhetoric de-emphasized claims about gay people's gender inversion and refocused on the assertedly sick, predatory nature of homosexuality. For example, Anita Bryant's 1977 campaign to repeal Dade County's law prohibiting antigay discrimination operated under the moniker "Save Our Children." 135 Rhetoric supporting the armed forces exclusion made an even greater shift, presenting a

132. These ordinances are reproduced in Eskridge, Privacy Regulation, supra note 48, at 82728 app. 5.

133. Florida Legislative INVESTigation COMM, REPORT OF THE FloRIDA Legislative INVESTIGATING COMMTTEE TO THE 1959 SESSION OF THE LEGISLATURE 4-5, available at Florida Dep't of State, Div. of Archives, ser. 1486, carton 1 (Tallahassee, Fla); see also FLORDA LEGISLATIVE INVESTIGATION COMM., HOMOSEXUALITY AND CITIZENSHIP IN FLORIDA 14 (1964) ("[T] he homosexual's goal ... is to 'bring over' the young person."), available at Florida Dep't of State, Div. of Archives, ser. 1486, carton 1 (Tallahassee, Fla.).

134. See JAMES W. BUtTon ET AL., PRIVATE LIVES, PUBlic Conflicts: Battles ovBR GaY RIGHTS IN AMERICAN COMMUNTIES 76-86 (1997) (noting that gay rights ordinances are most likely found in cities with racial diversity, nontraditional households, and dominant religions that do not emphasize women's roles as wives and mothers, and also noting that feminist groups are especially key allies).

135. Jane S. Schachter, The Gay Civil Rights Debate in the United States, 29 HARV. C. R. C.L.L. REV. 283, 284 nn.10-11 (1994). 
kinder, gentler, legalized version of the sexual predation argument: the privacy as well as morale of straight soldiers would be threatened by the shower-room gaze of openly gay comrades, which in turn threatens unit cohesion and the ability of the armed forces to do its job. The shower-room argument reflects the continuing power of American fears about sexuality. It also reflects the gendered nature of those fears, as men are much more hysterical about being sexualized by the homosexual gaze than women are. This is surely related to women's experience with being sexualized already by straight men, whose gaze is overwhelmingly more likely to be followed by a rape than the lesbian's gaze. The operation of the exclusion is also gendered, as female service personnel have long been and continue to be discharged at significantly higher rates than male personnel. This might reflect a greater incidence of lesbians than gay men in the armed forces, but it also reflects sexist assumptions about military service (man's work) and women's place (if not in the home, in a man's bed). ${ }^{136}$ Even though they have virtually vanished from public antigay rhetoric, the prevalence of sexist assumptions is revealed by continuing folk discourse about gay people, eśpecially popular and even academic obsession with the "sissy" or effeminate gay man and the "mannish" lesbian. ${ }^{137}$

\section{The Sex Discrimination Argument for Homo Equality in Light of the Multiple Roots of Homophobia}

The foregoing history provides important but qualified support for the sex discrimination argument for homo equality. The account supports Adrienne Rich's view that the law's operation against lesbians in particular has been and remains directly inspired by cultural resistance to women's deviation from traditional gender norms. The bargaining position for all women within the military, in marriage, and in child custody disputes is undermined by social and legal disapproval of women having sex with or partnering with other women. That women as well as men disapprove of lesbian relationships can be attributed largely to narcissistic emotional needs to create a stable identity in opposition to the lesbian "Other," a process the law intensely supported in the past and more weakly supports today. In my view, the hysterical and obsessional features of homophobia are much less prominent in antilesbian prejudice. Straight male pornography regularly deploys women having sex with one another before they or one of them has sex with a man, and the popularity of this motif suggests that sex between two women disgusts straight men only if the women are permanently unavailable for sex with men. Fears of lesbian conspiracies may become more pronounced as women achieve greater power in our culture, but this obsessional theme seems subordinate to the narcissistic theme.

136. See Michelle M. Benecke \& Kirstin S. Dodge, Military Women in Nontraditional Fields: Casualies of the Armed Forces War on Homosexuals, 13 HARV. WOMEN's L.J. 215, 219 (1990); Kenneth L. Karst, The Pursuit of Manhood and the Desegregation of the Armed Forces, 38 UCLAL. Rev. 499, 546 (1991) (linking military's segregation of women and exclusion of gays).

137. See POSNER, supra note 40, at 296-97, analyzed in William N. Eskridge, Jr., A Social Constructionist Critique of Posner's Sex and Reason: Steps Toward a Gaylegal Agenda, 102 YALEL.J.333 (1992). 
But the account demonstrates that compulsory heterosexuality as to men is animated by something more than rigid gender roles; it is animated by anxiety about sexuality itself. Although early disapproval of male sexual inverts was fueled largely by narcissistic anxieties, the hysterical and obsessional features of homophobia have since World War I more strongly contributed to social disapproval of and even violence against gay and bisexual men. The predatory homosexual (man) has been a more powerful rallying point for homophobia than the vampire lesbian. Even today, in debates over same-sex marriage, the natural law opponents often claim that "homosexuals" convey venereal disease (including the virus that causes AIDS) and prey on children, even though the data makes clear that it is men generally (and not gay men alone) who do these things and that lesbians seem to have the lowest rates of AIDS and child molestation of any of the groupings.

If the sex discrimination argument for homo equality falters in any way with respect to bisexual and gay men, it loses little or none of its power with respect to gay and bisexual women. For example, sodomy laws, including laws regulating only same-sex sodomy, reflect a sex negativity directed primarily at the most sexualized group in our society, gay and bisexual men. Huber Walsh, the defendant in the Missouri case, was arrested for fondling a decoy cop as a physical overture for sex. ${ }^{138} \mathrm{Walsh}$ is representative of the declining number of people arrested for consensual sodomy. Most of the cases challenging consensual sodomy laws in the 1970 s and 1980s involved gay or bisexual men cruising parks and streets for anonymous sex. Although men are the only gay people arrested under these laws - as they are ridiculously easy to catch-the laws are deployed against lesbians in custody and other legal proceedings and hence reinforce their sexist effect. For the foregoing reasons, the sex discrimination argument outlined in Table 2 is fully applicable to laws that make intercourse between two women, but not a woman and a man illegal: the law classifies based on the sex of one of the partners, which is sex discrimination in the same way that the law in McLaughlin was race discrimination; ${ }^{139}$ the sex-based classification on its face confines women to traditional gender role of availability for sex with men; the anxieties underlying the prohibition are for the most part the narcissistic anxieties that sexism and homophobia most intimately share. The sex discrimination argument outlined in Table 2 is substantially applicable to laws that make intercourse between two men, but not a woman and a man, illegal: the law classifies based on the sex of one of the partners, which is sex discrimination; the sex-based classification on its face confines men to traditional gender role of man-fucks-woman; the anxieties underlying the prohibition are narcissistic anxieties that sexism and homophobia most intimately share, as well as hysterical and obsessional anxieties that are not directly sexist but that are gendered (many people do not find oral sex between a man and a woman disgusting in the way they see oral sex between two men).

The narcissistic feature of homophobia seems to be the dominant reason for state refusal to recognize same-sex marriages for men as well as women. The most popular arguments against same-sex marriage are that marriage is "definitionally"

138. See State v. Walsh, 713 S.W.2d 508, 509 (Mo. 1986) (en banc).

139. McLaughlin v. Florida, 379 U.S. 184, 195 (1967). 
male-female and, relatedly, that same-sex marriage would undermine the institution by obliterating that important requirement of sex differentiation. These are openly gendered arguments, but another is not. Some opponents argue that recognizing same-sex marriage would place a state stamp of approval on unions that are by nature unclean and promiscuous, an appeal to the hysterical feature of homophobia. But the revulsion some people have to sodomy cannot explain opposition to samesex marriage, because so many heterosexuals engage in such conduct, often within marriage. To the extent sodomy is invoked to oppose same-sex marriage, it is only same-sex sodomy and its inversion of the gendered role of at least one of the partners. Although invoked as an argument against same-sex marriage by traditionalists, the stereotype of the homosexual (male) as sexually promiscuous would on the whole support the idea of homosexual marriage. Marriage in our culture is a safe haven, channeling sex in productive directions, as a cement for partnership and family. The hypersexualized person-the homosexual man-would seem to need the civilizing features of marriage even more than the normally sexualized person. Indeed, under traditionally gendered understandings, marriage has been considered just as necessary for the super-sexualized male as for the less sexualized female, because the institution civilizes the male and productively channels his sexual energy. The sodomy revulsion and the supersexuality revulsion work together, in fact: a married gay male couple will sublimate their supposed excess sexual energy and presumably engage in less sodomy, as the reasoned opponents of same-sex marriage concede.

Moreover, the fidelity argument also illustrates the gendered nature of objections to same-sex marriage. The wildest, most beast-like heterosexual man is allowed to marry, and the Supreme Court has held that even convicted murderers and rapists have a presumptive right to marry. ${ }^{140}$ Society and the polity encourage even the wild man to marry because of the traditional belief that a "domesticating" woman could tame the wild man. Society does not entertain this belief for two men who want to marry, in part because of gender stereotypes about men and the assumed absence of children. (It is not clear whether the fidelity argument has any power for lesbian marriages.) If same-sex marriage holds out no hope for taming the wild beast, it can once more be traced to the strong hold that traditional gender attitudes exercise in our culture-and another reason why the sex discrimination argument for homo equality works so well in the context of same-sex marriage.

\section{PRAGMatic ObJeCtions to Homo EQuality}

The three biggest discriminations against gay people in America today are laws criminalizing consensual sodomy, the military exclusion, and state and federal bars to legal recognition of same-sex marriages. Ironically, the discrimination with the greatest doctrinal support-laws criminalizing "homosexual sodomy," legitimated by Hardwick-is the discrimination that has been and will continue to be challenged most successfully; it is also the discrimination with the least support among commentators. In contrast, the military exclusion and same-sex marriage bars are the most doctrinally vulnerable but are widely thought to be impregnable

140. See Tumer v. Safley, 482 U.S. 78, 101 (1987). 
to constitutional challenge. And virtually no one who thought the military exclusion or the same-sex marriage bar impregnable before Evans has changed her or his mind after the Supreme Court's decision. The nicest critic of homo equality, Judge Richard Posner, says that the killer argument is naked pragmatism: however logical or moral the case for same-sex marriage or gays in the military, those gay-friendly policies are too unpopular for the Supreme Court to force upon an unwilling nation. ${ }^{141}$ This pragmatic objection to homo equality requires further exploration, for what it reveals about equal protection and constitutional theory as well as its implications for homo equality.

Philip Frickey and I anticipated Posner's point as part of a political theory of the Court's public law jurisprudence. We maintained that the Court's public law decisions consider both rule of law and policy arguments but also contain a strategic element: In making choices, even in constitutional cases, the Court will be influenced not only by legal texts, precedent, policy ramifications, but also by signals from the President, Congress, and the public as to their reaction to different possible decisions. ${ }^{142}$ The Court will never ignore and rarely seek to upset a political equilibrium (consensus) against a particular proposition, such as same-sex marriage. Consistent with our theory and contrary to Carolene Products, the Court's practice in equal protection cases rarely protects completely powerless minorities against special censure and penalties widely accepted among the population and its elites. Instead, the Court tends to protect once powerless groups only after it has become clear that the group is politically mobilized and potentially a partner in the pluralist system. Once the Court realizes that a previous political equilibrium has shifted, it will move public law in the same direction. Thus, the Court did not strike at apartheid until it had become a national embarrassment (Brown), did not invalidate miscegenation laws until they had been repealed everywhere outside the South (Loving), did not seriously review state and federal sex discriminations until the Equal Rights Amendment was passed by large majorities in Congress (Craig), did not nullify state sodomy laws when half the states still had them (Hardwick), but pounced on a squirrelly antigay initiative adopted by narrow margins in an outlier state (Evans).

Posner's pragmatic stance is dismissive of the constitutional arguments for samesex marriage and, probably also, gays in the military. At first glance, the broader pragmatic idea of law as equilibrium seems to cut in the same direction. But the matter is not so simple, and Evans is recognition that even pragmatic theories of law must take seriously the claims of homo equality. Specifically, pragmatic theories cannot ignore principle in a period of shifting equilibrium and ought to recognize the modestly positive role that the judiciary can play in assuring the conditions of equal citizenship for previously marginalized Americans.

141. POSNER, supra note 40 , at 318 (observing that gays in the military and same-sex marriage are too daring for courts to accomplish); Richard A. Posner, Should There Be Homosexual Marriage? And IfSo, Who Should Decide?, 95 MrcH. L. REv. 1578, 1585-86 (1997) (reviewing ESKRIDGE, supra note 106).

142. See William N. Eskridge, Jr. \& Philip P. Frickey, The Supreme Court, 1993 Term -Forward; Law as Equilibrium, 108 HARV.L. Rev. 26, 46-47 (1994). 


\section{A. Procedural Strategies for Coping with the Pragmatic Dilemma in a Time of Shifting Political Equilibrium}

Posner asserts that the Supreme Court dare not accept the logical arguments for same-sex marriage, but the Supreme Court should be equally wary of rejecting the arguments by an open appeal to Posner's reasoning, for it would expose the Court as unprincipled. The Court would, in short, have to write a more persuasive opinion than the one it wrote in Hardwick. ${ }^{143}$ By narrowly focusing on and disrespecting "homosexual sodomy," the Court came close to the kind of analysis Posner makes against same-sex marriage. But even that indirect version of Posner's argument brought widespread academic scorn upon the Court, as commentators-including Posner-feasted on the Court's opinion like famished dieters. Moreover, the Court's opinion mistook the intensely homophobic past for the future and got caught in a normative transition that soon afterward also overwhelmed Judge Bork: The American people, including many sex-negative Americans, believed in the privacy of one's bedroom and viewed with distaste the state nosiness Hardwick exposed. The Court faces a similar, albeit indeterminate, danger in a same-sex marriage case. An analytically or factually flawed opinion would open the Court to harsh criticism and fresh charges of antigay bias, especially if public opinion shifted on the issue. ${ }^{144}$ Even worse, for the Court, an unpersuasive opinion would further expose the Court's activism in cases where racial classifications seek to remedy the continuing legacy of apartheid. Consider an analogy to affirmative action.

In Adarand Constructors, Inc. v. Pena, the Court applied a nontextual (not in the Fifth Amendment) equal protection right to hold that federal affirmative action must be subjected to strict scrutiny. ${ }^{145}$ Unlike Loving, where the race-based classification was motivated by precepts of white supremacy, Adarand made the race-based classification the sole basis for strict scrutiny of a policy that was intended as a remedy for the very white supremacist philosophy that undergirded the antimiscegenation law in Loving. (Four dissenting Justices in Adarand rejected the deployment of strict scrutiny of apartheid-remediation programs.) Most striking is the analytical similarity between Adarand and Baehr, diagrammed in Table 3.

143. Bowers v. Hardwick, 478 U.S. 186:(1986).

144. And even if, as appears likely, it takes decades for public opinion to shift, who on the Court wants to go down in history as the author of an antigay version of Plessy v. Ferguson, 163 U.S. 537 (1896), overruled by Brown v. Board of Education, 347 U.S. 483 (1954)? (Pop quiz: As most law students and many lawyers know, Justice Byron White was the author of Hardwick. Can you name another majority opinion he wrote?)

145. 515 U.S. 200, 227, 237 (1995). 


\begin{tabular}{|c|c|c|c|}
\hline \multicolumn{5}{|c|}{ THE AFFIRMATIVE ACTION ANALOGY } \\
\hline & Classification & $\begin{array}{c}\text { Disadvantaged } \\
\text { Class }\end{array}$ & $\begin{array}{c}\text { Philosophical } \\
\text { Target }\end{array}$ \\
\hline Loving & Race & $\begin{array}{c}\text { Miscegenosexuals } \\
\text { (Racial Minorities) }\end{array}$ & $\begin{array}{c}\text { White } \\
\text { Supremacy }\end{array}$ \\
\hline Adarand & Race & $\begin{array}{c}\text { Racial } \\
\text { Majority }\end{array}$ & $\begin{array}{c}\text { Remediation for } \\
\text { Legacy of } \\
\text { Apartheid }\end{array}$ \\
\hline Craig & Sex & $\begin{array}{c}\text { Young Men } \\
\text { (Women) }\end{array}$ & Sexism \\
\hline Baehr & Sex & $\begin{array}{c}\text { Sexual Orientation } \\
\text { Minorities } \\
\text { (Women) }\end{array}$ & $\begin{array}{c}\text { Compulsory } \\
\text { Heterosexuality } \\
\text { (Sexism) }\end{array}$ \\
\hline
\end{tabular}

Analytically, Adarand and Baehr are similar, in that the suspect classification itself triggered heightened scrutiny, without any necessary link with traditional equal protection considerations, namely, a pervasively disadvantaged class and invidious, prejudice-based motivations. If Baehr is a radical extension of sex discrimination law, it is merely following the example of Adarand in race discrimination law. (Indeed, if homophobia is related to sexism, as Part II argues, Baehr is not radical at all and is required by the Court's sex discrimination precedents.) Conversely, a court claiming to subject remedial preferences to strict scrutiny on grounds of consistency with other equal protection race precedents, as the Court claimed in Adarand, ${ }^{146}$ should be subject to strong criticism for abandoning consistency and congruence with equal protection sex precedents. For the Court to be exposed to serious charges of unprincipled constitutional reasoning is bad enough; that the apparent motivation for the inconsistency would be pandering to public hostility to basic rights for gay people and minimal remediation for people of color, might undermine, perhaps seriously, the perceived neutrality of the Supreme Court.

If the Court dare not require states to recognize same-sex marriage but fears the risks of rejecting the sex discrimination argument without a defensible reason, the Court is in a bind. But there are ways of negotiating the bind, what Professor Alexander Bickel called 'techniques of 'not doing,' devices for disposing of a case while avoiding judgment on the constitutional issue it raises." ${ }^{.147}$ For the foreseeable future, the Court should leave state courts alone to develop the sex discrimination argument for same-sex marriage or against sodomy laws. Presumably, courts

146. Id. at 229 (rejecting the view that "benign" racial classifications should be reviewed leniently and insisting upon "consistency" whenever a suspect classification is under review).

147. AIEXANDER M. BICKEL, THE LEAST DANGEROUS BRANCH: THE SUPREME COURT AT THE BAR OF POLITICS 169 (1962). 
accepting a sex discrimination argument for homo equality would, like the Baehr court, rely on state constitutional grounds, over which the Supreme Court has no review authority. If a state court were bold enough to rely on the U.S. Constitution or if a gay couple losing at the state level were to seek federal constitutional review, the Supreme Court should avoid the case, either by denying review (which is fully within the Court's discretion) or finding the case prudentially or constitutionally nonjusticiable, if possible under the Court's precedents. The hardest case for the Court would be one where a lower court relied on federal constitutional law to invalidate a state same-sex marriage bar. The Supreme Court would have the power simply to deny review or even to dismiss any appeal on procedural grounds, ${ }^{148}$ leaving the decision in place for that particular state but also leaving the issue open for adjudication in other jurisdictions.

The wisdom of this approach is supported by the Court's experience in Hardwick. The court of appeals had invalidated the Georgia statute on federal right to privacy grounds. Because state and federal courts had taken a variety of positions on the constitutionality of consensual sodomy laws, it was certainly not odd that the Supreme Court would have granted review. As Justice Lewis Powell realized, however, the Court did not have a well-considered basis for disposing of the appeal. Powell himself was tom between a disinclination to assure gay people equal rights and a skepticism that the sodomy law was legitimately applied to private intercourse between consenting adults. ${ }^{149}$ The appropriate course of action, in that event, would have been to seek dismissal of the appeal as improvidently granted or to seek reversal of the lower court on the ground that the case was moot (Hardwick had been arrested but the charges were dropped). Deciding the case prematurely, and in an opinion laced with disrespect for gay people, has been more damaging to the Court's legitimacy than any other course of action the Court could have taken. With due deference to the Justices, I proffer that they have much to learn about same-sex marriage and therefore must not close off constitutional discourse on that subject prematurely.

\section{B. The Rule of Law and Tolerable Sexual Variation}

Under a conservative pragmatic theory such as Posner's, one would not expect the Court to adopt heightened scrutiny as a basis for reviewing sexual orientation classifications until a majority of the Justices accept the idea of benign sexual variation $^{150}$ and believe there is enough political cover for them to enforce the idea

148. If four Justices voted to grant review, the Court would have to hear the case, but if the remaining five Justices believed the case nonjusticiable they could vote to dismiss the appeal. Compare, e.g., New York v. Onofre, 451 U.S. 987 (1981) (denying certiorari for an appeal of the state court invalidation of a sodomy law on federal constitutional grounds), with Uplinger $v$. New York, 467 U.S. 246 (1984) (voting to dismiss an appeal of the state court invalidation of the solicitation of "deviate sexual relations" law).

149. See JOHN C. JEFFRIES, JR., JUSTICE LEWIS F. POWRLL, JR. 519-20 (1994).

150. "Benign sexual variation" is anthropologist Gayle Rubin's term for the idea that there may be several rather than just one healthy sexual orientation. Gayle Rubin, Thinking of Sex: Notes for a Radical Theory of the Politics of Sexuality, in PLRASURE AND DANGRR: EXPLORING FEMALE SEXUALITY 267, 283 (Carole S. Vance ed., 1984). 
under the Equal Protection Clause. Because the Court accepts the ideas of benign racial, gender, and religious variation, and the country's public culture is at least acquiescent, the Court will not allow state penalties because of an individual's race, gender, or religion. Because the Justices probably do not accept the idea of benign sexual variation and the country decidedly does not, neither prerequisite for heightened scrutiny of sexual orientation classifications is in place, but if the Court or the country were to move toward these precepts in the new millennium, virtually all the foregoing discriminations would become embattled and fall away, as racebased and sex-based classifications have done.

Perhaps for the foregoing reason, Evans did not address the issue of heightened scrutiny for sexual orientation classifications. But even a conservative pragmatism ought to support a reading of Evans that commits the current Court to the idea of tolerable sexual variation, that most variations in sexuality ought to be tolerated by the state, even if not embraced or encouraged. This reading of Evans is morally, politically, and legally defensible. It is morally defensible because there is no credible evidence for the proposition, still accepted by many Americans, that sexual variation is necessarily a defect. Not only is there no credible evidence that people whose orientation is toward people of their own sex are mentally or psychologically dysfunctional or harmful to others, but there is substantial evidence that gay people are as functional as straight people. ${ }^{151}$

A reading of Evans that insists on state toleration of sexual minorities is also politically defensible, even in a polity containing many people who find the minority repugnant. Whatever the ultimate status of gay people in the United States, they will remain a visible and significant citizenry for the foreseeable future. Unless gay people systematically harm others, the state cannot afford to demonize them through laws criminalizing their consensual conduct, exclusions from the civil service, and intrusions into their family life. Intolerance induces a destructive process of state witch-hunts and private hiding, thereby squandering valuable human resources that could be expended in producing public benefits and problem-solving. At the very level of two-person cooperation, when one person feels she has to be guarded and secretive about herself, the whole enterprise of cooperation will be compromised, if only a little. Multiplied manifold, this social loss is very significant. State intolerance also creates unnecessary risks for a society, especially the possibility of a malignant dynamic of anger. When the state makes it a crime to express oneself as a Jew, as a lover of Africans, or as a homosexual, the state is likely to embitter the objects of the suppression and to empower its own worst bigots. As to the later, the person who is most likely to enforce rules of suppression is a person who feels the most intense animosity toward the targeted class. By empowering such people, the state is rewarding its most potentially vicious citizens. By demonizing a viable and nonharmful community, the state is inviting social turmoil. ${ }^{152}$ Kulturkampf-a

151. Lest I be misunderstood, there is nothing in the foregoing statements that pertains to other kinds of sexual variation. For example, the moral issues presented by people who are attracted to prepubescent children (most of whom are heterosexual) are substantially different than those presented by people who are attracted to adults of either sex.

152. See Richard H. McAdams, Relative Preferences, 102 YALE L.J. 1, 98 (1992). 
state campaign to erase a nomic minority-is politically destructive as well as morally squalid.

Finally, rule of law ideas support a reading of Evans that requires state toleration of gay people. In a liberal polity, the rule of law, neutrally applied, facilitates both public obedience and private cooperation. If the law stands ready to enforce private obligations and protect against public intrusions for all citizens and without discrimination, each citizen is more likely to obey the law herself and to think that she can trust others to deal with her in a nondiscriminatory way. If the law is intolerant of gay people, the state is sending a signal that they cannot rely on the law in the ways that others can; that signal, in turn, suggests to its recipients that they are outside the rule of law, which in turn ought to render them less likely to obey the law and to cooperate with outsiders. The human and social costs of this exercise are manageable if the group is small and destructive (e.g., drug dealers); they are potentially large if the group is substantial and productive (e.g., gay people). As Evans implicitly recognized, a robust defense of nondiscrimination laws is a state signal that public and private intolerance cannot proceed along specified lines of race, sex, and increasingly sexual orientation.

Evans ought to be read to institute a principle of gay tolerance in equal protection law. Such a principle would be presumptively skeptical of consensual sodomy laws, especially those applicable only to same-sex sodomy; bars to adoption and presumptions against child custody by lesbian, gay, bisexual, and transgendered parents; and employment exclusions. A principle of tolerance would not necessarily require the state to recognize same-sex marriage and would be open to a don't ask, don't tell policy in the armed forces.

As to the latter, a neutral rule of law regime ought to be sympathetic to a policy seeking a middle ground between two competing rights. In the close-quartered context of the armed forces, there may be such competing rights-the right of gay people to serve in the armed forces and the right of homophobes not to share showerrooms with people they fear. As a matter of equal protection, it might be acceptable to require gay personnel to be discreet in return for allowing them to serve. The problem with the military's don't ask, don't tell policy, however, is that it is inherently unstable, because obsessional homophobes will insist on asking and even discreet gay people often end up telling, sometimes completely by accident.

\section{Shared Values, Normative Discourse, and Benign Sexual Variation}

If conservative pragmatists are right that cultural consensus can influence public law, a progressive pragmatist might ask why law cannot influence cultural consensus. ${ }^{153}$ The Supreme Court has the power, which it exercised in Evans, to stimulate discussion about the nature of homophobia and the appropriate role of the state. By imposing heightened scrutiny on state policies that discriminate against gay people, the Court has the further power to place the burden of persuasion as to

153. On the differences between conservative pragmatism, exemplified by William James, and progressive pragmatism, exemplified by Richard Rorty, see William N. Eskridge, Jr., Gaylegal Narratives, 46 STAN. L. RBV. 607, 622 (1994). 
antigay policies on the state rather than on gay challengers. This would trigger an increased number of challenges and would be fatal to most types of discriminations. As to those discriminations, American opinion is divided enough that the Court's action could be the signal which "tips" public discourse from viewing homophobia as morally or politically acceptable, to viewing it as unacceptable in public culture, the way open racism and sexism now are. On issues such as open antigay discrimination by public police forces, in the civil service, and in child custody and adoption, public opinion is divided enough for skeptical scrutiny by the Supreme Court or a state supreme court to prove fatal to such policies. Given their irrationality and frequent injustice, there is no good reason of equal protection principle or even of political pragmatism not to strike them down.

As to more controversial matters such as the military exclusion and, most prominently, same-sex marriage, the Court's fear is that activism in favor of gay rights would be understood as placing a state or judicial "stamp of approval" on "homosexuality," would generate a constitutional amendment overriding pro-gay decisions generally, and would tip public opinion against the Court itself. This was the Court's fear in 1955-1956, expressed by its decisions in Naim v. Naim, ${ }^{154}$ which refused in the wake of Brown to strike down laws prohibiting different-race marriage, then operative in most states. Only after states outside the south had repealed their laws did the Court strike them down in Loving. ${ }^{155}$ The lesson of Naim and Loving, however, is not that the Court needs to kowtow to hostile public opinion, but rather that the Court needs to proceed cautiously when pressing equality rights in the most controversial contexts for those rights. The Court in Naim anticipated Bickel's theory ${ }^{156}$ of doing good by not doing anything: The Court remanded the miscegenation law case to the Virginia Supreme Court for implicit reconsideration in light of Brown. ${ }^{157}$ The Virginia court reaffirmed its prior opinion upholding the law based upon natural law reasoning, ${ }^{158}$ and the Supreme Court dismissed the final appeal on a (rather implausible) procedural technicality. ${ }^{159}$ However unprincipled the decision might have been, it had this virtue: At no point did the Court approve or sanction laws against different-race marriage, leaving time for the issue to percolate in the lower courts. Loving itself was handed down only after the Court had sent up a successful trial balloon in McLaughlin, which struck down a law prohibiting different-race cohabitation. Moreover, the Court's successful action in Loving has contributed to shifting public opinion on the issue of different-race marriage. While half of the country still disapproves of such marriages for themselves or their children, an overwhelming majority believe that

154. 87 S.E.2d 749 (Va.) (declaring the marriage between a Chinese and a Caucasian void), vacated, 350 U.S. 891 (1955) (per curiam), adhered to on remand, 90 S.E.2d 849 (Va.), motion to recall mandate denied, 350 U.S. 985 (1956) (per curiam).

155. The Hawaii Supreme Court's unexpected decision in Baehr generated a strange override effort, in which Hawaii voters are being asked to amend the state constitution to empower the legislature to override any ultimate decision by the court requiring the state to issue marriage licenses to same-sex couples.

156. See supra text accompanying note 147 .

157. See Naim v. Naim, 350 U.S. 891 (1955) (per curiam).

158. See Naim v. Naim, 90 S.E.2d 849, 850 (Va. 1956).

159. See Naim v. Naim, 350 U.S. 985 (1956) (per curiam). 
the matter should be one of individual choice and not prohibited by the state. A final lesson of Loving for same-sex marriage is that such litigation initially needs to proceed at the state level. So long as there is not a single state in the union that recognizes same-sex marriages, federal constitutional arguments for them will not get beyond the Naim threshhold.

Theoretically the Court has the power not only to induce more tolerant, cooperative attitudes in the public sphere, but also to induce new shared values in the private sphere if it commits itself to formal equality for a previously excluded group. One reason has to do with a politics of presence: Once mainstream people work and cooperate with people of the excluded group, they tend to form more favorable attitudes and discard at least some of the inaccurate stereotypes. The most dramatic illustration of this process was the desegregation of the armed forces between 1948 and 1954. White soldiers and officers overwhelmingly opposed desegregation, based on racist fears about people of color, but after experience with such people whites supported or acquiesced in the policy. ${ }^{160}$ Desegregation, of course, occurred by order of President Truman and not by order of the Supreme Court, which undermines its precedent as an argument for the Supreme Court to override the President and Congress to overturn the don't ask, don't tell policy. But this example dramatically confirms the importance of institutional context in shaping private preferences.

On the issue of same-sex marriage, courts can at least do what the Hawaii Supreme Court did in Baehr: put the issue on a local agenda and reverse the presumption, from one prohibiting such marriages to one favoring them. If samesex marriages are recognized in Hawaii or another state, even if just for a period of time, that recognition would have none of the immediately dramatic consequences hoped for by gay rights leaders or feared by the most intense homophobes. As the example of Denmark reveals, one might expect several thousand couples, including many out-of-staters, to take advantage of the state recognition. Few if any states would immediately follow Hawaii's example, nor would many states recognize Hawaii same-sex marriages in their jurisdictions. God would not send the locusts on America. Yet the judicially triggered change in the law would instantiate norms yet to be determined. My guess is that same-sex marriage, even if deployed by a modest number of couples, would contribute, perhaps in just minor ways, to norms of toleration, family values, and sexual moderation. Gay people, including gay couples, would find an increasing social acceptance over time and, more importantly, would become increasingly integrated into mainstream religions and extended families. Marriage would have some impact in reducing sexual promiscuity, especially among gay and bisexual men, and would contribute to the public health campaign against AIDS. The institution of marriage would be strengthened by the enthusiastic new recruits, and a little bit more stability could be assured for children reared in same-sex households. Without believing for a second that same-sex marriages will be free of the problems already associated with different-sex marriages, and some new problems yet to be uncovered, I am confident that same-sex marriage will in little ways be good for gay people, good

160. See MORRIS J. MACGREGOR, JR., INTEGRATION OF THE ARMED FORCES, 1940-1965, at 40, 408-10, 441-42 (1981). 
for straight people, and good for America. And if I am wrong, the experiment will prove me wrong. Let it begin. 